\title{
Present-Biased Preferences and Credit Card Borrowing ${ }^{\dagger}$
}

\author{
By Stephan Meier and Charles Sprenger**
}

\begin{abstract}
Some individuals borrow extensively on their credit cards. This paper tests whether present-biased time preferences correlate with credit card borrowing. In a field study, we elicit individual time preferences with incentivized choice experiments, and match resulting time preference measures to individual credit reports and annual tax returns. The results indicate that present-biased individuals are more likely to have credit card debt, and to have significantly higher amounts of credit card debt, controlling for disposable income, other socio-demographics, and credit constraints. (JEL D12, D14, D91)
\end{abstract}

\begin{abstract}
redit card debt is widespread. US households with at least one credit card report carrying, on average, \$3,027 in revolving debt (based on the 2004 Survey of Consumer Finances). There is, however, significant heterogeneity in credit card borrowing. Only 45 percent of card holders report that they, at least sometimes, carry balances on their credit cards. Among these individuals, average credit card debt is $\$ 5,799$. These figures illustrate two important stylized facts of credit card debt. First, the level of card borrowing is substantial (and likely much higher than these selfreported figures suggest, as discussed later in this paper). Second, some individuals charge to their credit cards significantly, while others accumulate no debt at all.

This paper tests whether heterogeneity in individual time preferences correlates with credit card borrowing. In a large field study, we measure individual time preferences using incentivized choice experiments and link resulting impatience measures to administrative data on borrowing. In particular, we investigate whether individuals who exhibit present-biased preferences, that is, those who show a particular desire for immediate consumption, have higher credit card balances.
\end{abstract}

\footnotetext{
* Meier: Columbia University, Graduate School of Business, Uris Hall, 3022 Broadway, New York, NY 10027 (e-mail: sm3087@columbia.edu); Sprenger: University of California at San Diego, Department of Economics, 9500 Gilman Drive, La Jolla, CA 92093 (e-mail: csprenge@ucsd.edu). This paper is a substantial revision of the previous paper entitled: "Impatience and Credit Behavior: Evidence from a Field Experiment." We are grateful to two anonymous referees, Christine Benesch, Mary Burke, Jeff Carpenter, Vince Crawford, Jonathan Crook, Chris Foote, Andreas Fuster, Kris Gerardi, Lorenz Goette, Glenn Harrison, David Huffman, Elif Incekara, Cathleen Johnson, Jane Katz, David Laibson, Borja Larrain, Felix Oberholzer-Gee, Jan Potters, Tanya Rosenblat, Julio Rotemberg, Jeremy Tobacman, Tyler Williams, and participants at seminars and conferences at Columbia University, the Dutch Nationalbank, the European University Institute, the Federal Reserve Bank of Boston, the Federal Trade Commission, the University of Arizona, the University of Lausanne, the University of Texas at Dallas, and the University of Zurich for helpful comments. This research was undertaken while both authors were at the Federal Reserve Bank of Boston. Special thanks to Marques Benton (Department of Public and Community Affairs) for his help. The views expressed herein are solely those of the authors and not necessarily those of the Federal Reserve System or the Federal Reserve Bank of Boston.

$\dagger$ To comment on this article in the online discussion forum, or to view additional materials, visit the articles page at: http://www.aeaweb.org/articles.php?doi=10.1257/app.2.1.193.
} 
A number of theoretical papers suggest that present bias drives credit card borrowing (e.g., David Laibson 1997; Ernst Fehr 2002; Paul Heidhues and Botond Köszegi 2008). Present bias is argued to increase individuals' desire for instantgratification and, as a result, increase borrowing. ${ }^{1}$ However, there has been very little direct evidence to support the behavioral economics view that present-biased individuals borrow more.

Previous research on present bias and credit card debt used one of two approaches: examining aggregate debt measures or examining self-reported debt measures. Both of these approaches have limitations for examining the relationship between individual present bias and credit card debt. Studies using the first approach analyze aggregate credit and savings outcomes and show that models of consumer behavior with present-biased preferences predict aggregate consumption behavior better than standard exponential models (Laibson, Andrea Repetto, and Jeremy Tobacman 2008; Paige Marta Skiba and Tobacman 2007; Haiyan Shui and Lawrence M. Ausubel 2005) 2 These studies are important as they indicate that, in the aggregate, presentbiased preferences are able to explain anomalies such as consumers simultaneously holding credit card debt and low-yield assets. The link between borrowing and present bias is, however, indirect. Additionally, examination of aggregates does not allow for evaluation of individual behavior.

A second approach measures individual time preferences directly with choice experiments, and correlates these measures to self-reported credit balances or spending problems. Glenn W. Harrison, Morten I. Lau, and Melonie B. Williams (2002) find that individual long-run discount factors do not correlate with borrowing behavior, though their study says nothing about the association between present bias and credit card borrowing 3 Using measurement techniques similar to our own, Thomas Dohmen et al. (2006) show that present-biased individuals report having more problems restricting their spending 4 Though these studies provide important indications that exponential discount factors alone do not correlate with borrowing, or that present bias is associated with spending problems, the accuracy of the self-reported measures from these studies is particularly difficult to assess. People generally either underreport their debt levels or lie altogether (for details, see David B. Gross and Nicholas S. Souleles 2002; Karlan and Zinman 2008; Zinman 2009). It is therefore critical to analyze objective data on credit card borrowing.

\footnotetext{
${ }^{1}$ Present-biased preferences can be seen as the result of the interplay of two separate decision making systems: the affective system, which values immediate gratification and sharply discounts all future periods; and the deliberative system, which makes long-run plans and displays higher discount factors. This notion is captured in various models (for example, Ted O'Donoghue and Matthew Rabin 1999; Faruk Gul and Wolfgang Pesendorfer 2001; Carol Bertaut and Michael Haliassos 2002; B. Douglas Bernheim and Antonio Rangel 2004; George Loewenstein and O'Donoghue 2004; Drew Fudenberg and David K. Levine 2006) and finds support in neuroeconomics studies (Samuel M. McClure et al. 2004, 2007).

${ }^{2}$ Another set of studies show behavioral patterns in field data consistent with present-biased preferences (e.g., Dan Ariely and Klaus Wertenbroch 2002; Xavier Gine, Dean Karlan, and Jonathan Zinman 2008; Sharon M. Oster and Fiona M. Scott Morton 2005).

${ }^{3}$ By design, all experimental payments in Harrison, Lau, and Williams (2002) were received with a minimum delay of one month, eliminating potential identification of present bias.

${ }^{4}$ Nava Ashraf, Karlan, and Wesley Yin (2006) also directly elicit present-bias parameters using hypothetical choices and correlate present bias to take-up of a savings commitment device. They do not, however, analyze the relationship between present bias and debt.
} 
This study overcomes the limitations of both previous approaches by combining directly elicited time preference measures with administrative data on borrowing. This approach provides direct evidence on the link between present bias and credit card borrowing using objective, administrative data that eliminates the confounding factor of truthfulness in self-reported debt levels. For a sample of about 600 low- to moderate-income (LMI) individuals, we measure time preferences using incentivized choice experiments. The choice experiments allow us to measure individual discount factors, and to identify individuals who exhibit dynamically inconsistent time preferences (e.g., present bias). Resulting parameter estimates are linked to individual credit reports and tax returns. Credit reports give objective information on card borrowing and credit constraints; and tax returns provide objective information on individual incomes.

Our results show that experimentally measured present bias correlates highly with credit card borrowing. Individuals who exhibit present-biased preferences have substantially higher revolving credit balances. In our sample, present-biased individuals are about 15 percentage points more likely than dynamically consistent individuals to have any credit card debt. Conditional on borrowing, present-biased individuals borrow about 25 percent more than dynamically consistent individuals. The association between present bias and credit card borrowing holds when controlling for income, credit constraints (both credit access and credit limits), and socio-demographic characteristics. These results are the first direct support for behavioral economics models claiming that credit card debt is related to present-biased preferences.

The paper proceeds as follows. Section I discusses the design of the field study, our methodology for eliciting time preferences, and the data. Section II presents results, and Section III concludes.

\section{Data}

\section{A. Field Study Design}

The field study was conducted with 606 individuals at two Volunteer Income Tax Assistance (VITA) sites in Boston, MA. ${ }^{5}$ During the 2006 tax season, the study was conducted in the Dorchester neighborhood $(N=139)$. During the 2007 tax season, the study was conducted in the Roxbury neighborhood $(N=467)$. The two years differ mainly in the way in which time preferences were elicited (discussed in detail later in this paper).

We obtained consent from all participants to access their credit reports and to retrieve income information from their tax returns. Additionally, we surveyed participants to obtain certain socio-demographic characteristics (most likely measured with more error than information from tax data), and elicited their time preferences using incentivized choice experiments. We obtain a usable measure of time

\footnotetext{
${ }^{5}$ There are currently 22 VITA sites in and around Boston. Coordinated by a city-wide coalition of government and business leaders, VITA sites provide free tax preparation assistance to LMI households. Taxes are prepared by volunteers throughout each tax season.
} 
preferences for 541 of the 606 individuals who participated (see Section IC for details). These individuals represent our primary study sample.

Panel A of Table 1 shows the socio-demographic characteristics of all participants (column 1), and for those in our primary sample (column 2). The average participant has low disposable income of around $\$ 18,000$, is African American, female, about 36 years old, with some college experience, and has less than one dependent 6

As the summary statistics indicate, study participants were largely LMI/subprime borrowers. This nonstandard subject pool is of particular interest, as the less secure position of LMI and subprime households puts them at great financial risk (see Marianne Bertrand, Sendhil Mullainathan, and Eldar Shafir 2004). There are also very few experimental studies focusing solely on the behavior of LMI families in developed countries (an exception is Catherine Eckel, Cathleen Johnson, and Claude Montmarquette 2005). When interpreting the magnitudes of the presented results, the low income of participants should be taken into account. As in many experimental and survey studies, individuals select to come to the VITA sites and participate in our study. As we show in Meier and Sprenger (2008), study participants are more financially literate and more patient than individuals at the VITA site who elect not to participate. Though the direction of any potential bias is difficult to assess, one should keep the selection of the sample in mind when generalizing the results of this study.

\section{B. Credit Bureau Data}

Information on individual credit behavior was obtained from one of three major credit bureaus in the United States. The credit reports list detailed information on each individual's credit behavior, like outstanding balances and available credit limits (for details on credit reporting, see Robert B. Avery et al. 2003). Unlike selfreported data, credit reports give a very detailed, objective picture of individual borrowing behavioi 7

We measure credit card borrowing as outstanding balances on revolving accounts 8 Panel B of Table 1 illustrates the two stylized facts of credit card borrowing previously noted: high borrowing and substantial debt heterogeneity. The average credit card

\footnotetext{
${ }^{6}$ For a number of observations, we lack certain socio-demographic information (gender, race, and college experience). Each of these variables is binary. For the analysis below, we set missing values to the value of the majority and add indicator variables for missing gender, race and college experience in each regression. Excluding observations with missing variables does not affect the results (see Section IIB).

${ }^{7}$ Credit reports do not include nontraditional loan products (e.g., payday loans). For a subset of our sample in $2006(N=131)$, we use self-reported information on loans obtained from pawn brokers, check cashers, payday lenders, friends, family, or on any outstanding balances on bills due to medical providers, landlords, and utilities providers. Nontraditional debt of this type is relatively small, averaging \$372 (SD \$827) per person. Adding nontraditional debt to aggregate debt does not influence the results. As people often underreport their debt levels in surveys, we do not incorporate self-reported debt in our regression analysis.

${ }^{8}$ Though balances listed on credit reports are point-in-time measures, we argue that our borrowing measures closely reflect revolving balances and not convenience charges. In general, only around 5-10 percent of total balances are convenience charges (Kathleen W. Johnson 2004). Additionally, we implemented a companion survey with questions on credit card bill payment habits as worded in the Survey of Consumer Finances $(N=174)$. Individuals who report normally paying the full amount on their credit card at the end of the month (21 percent of the sample), have significantly lower balances on revolving accounts $(\$ 1,093$ versus $\$ 3,086 ; p<0.05$ in a $t$-test).
} 
Table 1 -Summary Statistics

\begin{tabular}{|c|c|c|c|c|}
\hline & $\begin{array}{c}\text { All } \\
\text { participants } \\
\text { (1) }\end{array}$ & $\begin{array}{l}\text { Primary } \\
\text { sample } \\
(2)\end{array}$ & $\begin{array}{l}\text { Present- } \\
\text { biased } \\
(3)\end{array}$ & $\begin{array}{c}\text { Not present- } \\
\text { biased } \\
\text { (4) }\end{array}$ \\
\hline \multicolumn{5}{|c|}{ Panel A. Socio-demographic variables } \\
\hline Age & $\begin{array}{c}35.8 \\
(13.8)[606]\end{array}$ & $\begin{array}{c}35.9 \\
(13.4)[541]\end{array}$ & $\begin{array}{c}33.8 \\
(12.9)[194]\end{array}$ & $\begin{array}{c}37.1 \\
(13.5)[347]\end{array}$ \\
\hline Gender $($ male $=1)$ & $\begin{array}{c}0.36 \\
(0.48)[569]\end{array}$ & $\begin{array}{c}0.35 \\
(0.48)[510]\end{array}$ & $\begin{array}{c}0.41 \\
(0.49)[185]\end{array}$ & $\begin{array}{c}0.32 \\
(0.47)[325]\end{array}$ \\
\hline Race (African American=1) & $\begin{array}{c}0.80 \\
(0.40)[548]\end{array}$ & $\begin{array}{c}0.80 \\
(0.40)[491]\end{array}$ & $\begin{array}{c}0.81 \\
(0.39)[178]\end{array}$ & $\begin{array}{c}0.79 \\
(0.41)[313]\end{array}$ \\
\hline College experience $(=1)$ & $\begin{array}{c}0.51 \\
(0.50)[522]\end{array}$ & $\begin{array}{c}0.52 \\
(0.50)[465]\end{array}$ & $\begin{array}{c}0.62 \\
(0.49)[173]\end{array}$ & $\begin{array}{c}0.45 \\
(0.50)[292]\end{array}$ \\
\hline Disposable income & $\begin{array}{c}18,084 \\
(13,695)[606]\end{array}$ & $\begin{array}{c}18,516 \\
(13,692)[541]\end{array}$ & $\begin{array}{c}17,361 \\
(14,151)[194]\end{array}$ & $\begin{array}{c}19,162 \\
(13,407)[347]\end{array}$ \\
\hline Dependents & $\begin{array}{c}0.51 \\
(0.84)[606]\end{array}$ & $\begin{array}{c}0.52 \\
(0.84)[541]\end{array}$ & $\begin{array}{c}0.41 \\
(0.72)[194]\end{array}$ & $\begin{array}{c}0.58 \\
(0.89)[347]\end{array}$ \\
\hline \multicolumn{5}{|l|}{ Panel B. Credit information } \\
\hline $\operatorname{Debt}(=1)$ & $\begin{array}{c}0.41 \\
(0.49)[606]\end{array}$ & $\begin{array}{c}0.41 \\
(0.49)[541]\end{array}$ & $\begin{array}{c}0.45 \\
(0.50)[194]\end{array}$ & $\begin{array}{c}0.39 \\
(0.49)[347]\end{array}$ \\
\hline Revolving balance & $\begin{array}{c}1,162 \\
(2,838)[606]\end{array}$ & $\begin{array}{c}1,059 \\
(2,414)[541]\end{array}$ & $\begin{array}{c}1,565 \\
(3,216)[194]\end{array}$ & $\begin{array}{c}776 \\
(1,761)[347]\end{array}$ \\
\hline Having a revolving account $(=1)$ & $\begin{array}{c}0.53 \\
(0.50)[606]\end{array}$ & $\begin{array}{c}0.53 \\
(0.50)[541]\end{array}$ & $\begin{array}{c}0.54 \\
(0.50)[194]\end{array}$ & $\begin{array}{c}0.52 \\
(0.50)[347]\end{array}$ \\
\hline Revolving credit limit & $\begin{array}{c}4,741 \\
(11,705)[606]\end{array}$ & $\begin{array}{c}4,764 \\
(11,850)[541]\end{array}$ & $\begin{array}{c}5,129 \\
(12,440)[194]\end{array}$ & $\begin{array}{c}4,560 \\
(11,520)[347]\end{array}$ \\
\hline FICO score & $\begin{array}{c}611 \\
(84)[437]\end{array}$ & $\begin{array}{c}610 \\
(84)[390]\end{array}$ & $\begin{array}{c}608 \\
(80)[133]\end{array}$ & $\begin{array}{c}610 \\
(86)[257]\end{array}$ \\
\hline \multicolumn{5}{|l|}{ Panel C. Time preferences } \\
\hline IDF & $\begin{array}{c}0.84 \\
(0.19)[606]\end{array}$ & $\begin{array}{c}0.83 \\
(0.19)[541]\end{array}$ & $\begin{array}{c}0.85 \\
(0.11)[194]\end{array}$ & $\begin{array}{c}0.81 \\
(0.23)[347]\end{array}$ \\
\hline Present bias $(=1)$ & $\begin{array}{c}0.36 \\
(0.48)[606]\end{array}$ & $\begin{array}{c}0.36 \\
(0.48)[541]\end{array}$ & $\begin{array}{c}1 \\
(0)[194]\end{array}$ & $\begin{array}{c}0 \\
(0)[347]\end{array}$ \\
\hline Future bias $(=1)$ & $\begin{array}{c}0.11 \\
(0.31)[606]\end{array}$ & $\begin{array}{c}0.09 \\
(0.28)[541]\end{array}$ & $\begin{array}{c}0 \\
(0)[194]\end{array}$ & $\begin{array}{c}0.14 \\
(0.35)[347]\end{array}$ \\
\hline
\end{tabular}

Notes: Summary statistics for different sample restrictions. The table shows means and standard deviations in parentheses, and the number of observations in brackets. Column 1 shows summary statistics for all individuals. Column 2 only looks at individuals who exhibit a unique switching point in the choice experiments. Columns 3 and 4 split individuals with unique switching points into those who exhibit present-biased preferences and those who do not.

balance is $\$ 1,059$ (standard deviation (SD) \$2,414), with 40 percent of participants carrying credit balances.

Credit reports provide crucial information on credit card holdership and revolving credit limits. In our sample, the average revolving credit limit is $\$ 4,764$ (SD $\$ 11,850)$, with 53 percent of study participants having no credit cards. Credit reports do not provide information on credit card interest rates. However, we use Fair Isaac Corporation (FICO) credit scores as a proxy for interest rates, as most financial institutions use risk-based pricing strategies (see Mark Furletti 2003). The average FICO score in our sample is 610 (median: 596), indicating that subjects likely face subprime interest rates given the common subprime cutoff of 620 . 


\section{Measuring Time Preferences}

Methodology.-Individual time preferences are measured using incentivized choice experiments. (For similar approaches, see Maribeth Coller and Williams 1999; Harrison, Lau, and Williams 2002; McClure et al. 2004; Tomomi Tanaka, Colin Camerer, and Quang Nguyen 2007. For a survey on measuring time preferences, see Shane Frederick, Loewenstein and O'Donoghue 2002.) We analyze decisions from two multiple price lists in which individuals are asked to make a series of choices between a smaller reward $(\$ X)$ in period $t$ and a larger reward $(\$ Y>\$ X)$ in period $\tau$. We keep $\$ Y$ constant and vary $\$ X$ in two time frames. In time frame $1, t$ is the present $(t=0)$ and $\tau$ is in one month $(\tau=1)$; and in time frame $2, t$ is six months from the study date $(t=6)$ and $\tau$ is seven months from the study date $(\tau=7) .{ }^{9}$ The delay length, $d$, is one month in both time frames.

The design of the choice experiments in 2006 and 2007 differed in two dimensions (for instructions used and summary statistics for the two years, see the Web Appendix). First, the values of $\$ X$ and $\$ Y$ were varied between 2006 and 2007 to check the robustness of the results to such variation. In 2006, $\$ Y=\$ 80$, and $\$ X$ was varied from $\$ 75$ to $\$ 30$. In 2007, $\$ Y=\$ 50$, and $\$ X$ was varied from $\$ 49$ to \$14. Second, the presentation of the choice sets was varied between 2006 and 2007. While in 2006 the order of the price lists was the same for each individual; in 2007, the order was randomized. In the results section, we analyze the data from the two years jointly, controlling for the year of study. The results are very similar between the two years (see the Web Appendix).

In order to provide an incentive for the truthful revelation of preferences, 10 percent of individuals were randomly paid one of their choices. This was done with a raffle ticket, given to subjects at the end of their tax filing, indicating which choice, if any, would be effective. To ensure the credibility of the payments, we immediately filled out money orders for the winning amounts, in the presence of the participants, then put the money orders in labeled, pre-stamped envelopes, and sealed the envelopes. The payment was guaranteed by the Federal Reserve Bank of Boston, and individuals were informed that they could go to VITA site coordinators to report any problems receiving payment. Money orders were mailed to the winner's home address on the same day as the experiment (if $t=0$ ), or in one, six, or seven months, depending on the winner's choice. All payments were mailed to equate the transaction costs of earlier and later payments. The payment procedure mimicked a frontend-delay design (Harrison et al. 2005). The details of the payment procedure were the same in both years, and participants were fully informed about the payment method 10

\footnotetext{
${ }^{9}$ Individuals were also asked to make choices between the present $(t=0)$, and in six months $(\tau=6)$, in a third time frame. As it may be cognitively more difficult to give dynamically consistent answers in this choice environment, responses from the third time frame are added to the analysis only as a robustness test. Results are qualitatively unchanged (see Section IIB).

${ }^{10}$ If individuals expect to move in the next seven months, they might question the likelihood that their mail would be forwarded to their new address in a timely manner. As movers might prefer payments in the present for logistical reasons, and not for reasons related to their underlying time preference, we asked individuals: "Do you expect to move in the next 7 months?" Whether individuals expect to move does not correlate with elicited time preferences and does not affect our results.
} 
Using monetary rewards and multiple price lists as a preference elicitation mechanism allows us to identify differences in patience and present bias between individuals. This methodology yields measures that are highly correlated with time preference measures derived from other methodologies (e.g., Ernesto Reuben, Paola Sapienza, and Luigi Zingales 2008; Christopher F. Chabris et al. 2008). Over time, time preference measures obtained from price lists have also been shown to be stable at the individual level (see Meier and Sprenger 2009). It is important to note that this research requires a reliable measure of the heterogeneity in time preferences between individuals, but not necessarily precise point estimates of the levels of parameters. Therefore, relatively less space in the following sections is dedicated to discussing parameter levels, and relatively more attention is given to the correlation between preferences and borrowing behavior.

Time Preference Measures.-In the two different time frames, individuals make choices between a smaller reward at time $t$ and a larger amount one month later. Using information from both price lists allows us to measure discount factors and to identify present and future bias.

- Individual discount factor (IDF): We estimate monthly IDFs by observing the point in a given price list, $X^{*}$, at which individuals switch from opting for the smaller, earlier payment to opting for the larger, later payment. That is, a discount factor is taken from the last point at which an individual prefers the earlier, smaller payment, assuming that $X^{*} \approx I D F^{d} \times Y$, where $d$ represents the delay length 11 As the delay length, $d$, is one month for the time frames analyzed here, $I D F \approx\left(X^{*} / Y\right)^{1 / 1}$. For example, if an individual prefers $\$ 75$ today over $\$ 80$ in one month, but prefers $\$ 80$ in one month over $\$ 70$ today, then we take $\$ 75$ as the switching point and calculate the monthly discount factor as $(75 / 80)^{1 / 1}=0.9412$ Making these calculations for the two multiple price lists yields two discount measures, $I D F_{t, \tau}: I D F_{0,1}, I D F_{6,7}$. We use the average of these calculated monthly discount factors as the $I D F$ in the main analysis.

- Present bias and future bias: Using two time frames allows us to identify dynamic inconsistency. Dynamically inconsistent individuals exhibit a bias toward either present or future payments. An individual is present-biased if he is less patient (lower IDF) when the smaller, earlier payment is received in the present $(t=0)$. We classify an individual as present-biased if $I D F_{0,1}<I D F_{6,7}$, and

\footnotetext{
${ }^{11}$ This formulation is equivalent to positing a linear utility function over the experimental outcomes and normalizing extra-experimental consumption (e.g., background consumption) to zero. This procedure simplifies the analysis considerably and is consistent with expected utility theory, which implies that consumers are approximately risk neutral over small stakes outcomes (Rabin 2000). However, parameters estimated from price lists may also capture differences across individuals in the degree utility function curvature (Steffen Andersen et al. 2008). As a robustness test, we control for a survey measure of individual risk attitudes. Controlling for risk attitudes does not affect the results of this paper (see Section IB).

${ }^{12}$ It should also be noted that the price list methodology does not elicit point estimates of the IDF but rather ranges of where the IDF lies. Our analysis accounts for this interval nature of the data when identifying present (future) bias and when exploring the relationship between $I D F$, credit constraints, and socio-demographics (see Table 2).
} 
as future-biased if $I D F_{0,1}>I D F_{6,7}$. For our primary analysis, we use indicator variables Present Bias $(=1)$ and Future Bias $(=1)$ following these classifications.

In robustness tests, we use several additional measures for present bias. First, we use the ratio $I D F_{6,7} / I D F_{0,1}$ as a measure of the intensity of present (future) bias. Second, we calculate a quasi-hyperbolic discounting function (Robert H. Strotz 1956; Edmund S. Phelps and Robert A. Pollak 1968; Laibson 1997; O’Donoghue and Rabin 1999), and use the resulting present-bias parameter, $\beta$. Third, we include additional information from a third time frame in which $t=0$ and $\tau=6$, and construct composite measures of dynamic inconsistency (see Section IB).

In order to have useable measures of $I D F$ and dynamic inconsistency, an individual must exhibit a unique switching point in each price list. In both years, about 11 percent of participants do not exhibit unique switching points. In the main analysis, we focus on a primary sample of the 541 individuals who do show unique switching points in all price lists. When we include individuals with multiple switching points in a robustness test, by using their first switching point, the results are maintained (see Section IB).

For participants in the primary sample (column 2 of Table 1), we measure a monthly discount factor, $I D F$, of 0.83 as shown in panel $\mathrm{C}$ of Table 1 . This discount factor is low, but consistent with previous research, which tends to find low discount factors in experimental studies (see Frederick, Loewenstein, and O'Donoghue 2002). Decisions on payday loans or used cars often imply much lower discount factors for subprime borrowers than measured by our experiment (e.g., Skiba and Tobacman 2007; William Adams, Liran Einav, and Jonathan Levin 2009). Thirty-six percent of study participants are classified as present-biased, and 9 percent are classified as future-biased. Dohmen et al. (2006) find a similar proportion of present-biased individuals in their sample ( 28 percent), but more future-biased individuals (38 percent). Our levels of dynamic inconsistency are somewhat more comparable to Ashraf, Karlan, and Yin (2006) who classify 27.5 (19.8) percent of their sample as present (future)-biased.

\section{Measurement Validation}

The method described above for measuring time preferences with incentivized choice experiments has many advantages (Frederick, Loewenstein, and O'Donoghue 2002), but also several challenges. Experimental responses are argued to be impacted by extra-experimental borrowing and lending opportunities (Coller and Williams 1999; Harrison, Lau, and Williams 2002; Harrison et al. 2005; Robin P. Cubitt and Daniel Read 2007), and also potentially associated with credit and liquidity constraints, and credit experience. In the present study, these issues take on particular importance, as we not only experimentally measure time preferences, but also correlate them with actual borrowing behavior.

The impact of extra-experimental borrowing and lending opportunities can be seen as an arbitrage argument. If an individual can borrow at a lower interest rate than the experimentally offered rate, then the individual should wait for later experimental payments, borrow outside the experiment, and repay with experimental 
earnings, thereby arbitraging the experiment with a "borrow low-save high" strategy. If an individual can lend (save) at a higher rate than the experimentally offered rate, a second arbitrage strategy is open, and the individual should take the earlier experimental payment and invest it at the available higher rate.

We argue that prevailing interest rates for LMI individuals leave open only one of these strategies. The lowest annual interest rate offered in the experiment, in either year, is about 27 percent (calculated as $\left(50 / 49^{12}-1\right)$, and the next lowest annual interest rate is about 110 percent. Study subjects are unlikely to have investment opportunites in excess of this rate. This feature of our experimental design largely eliminates the second arbitrage opportunity, primarily leaving open the strategy of borrowing low outside the experiment and saving high inside the experiment. Such a strategy would lead to a high degree of observed patience and dynamic inconsistency only when individuals' extra-experimental opportunities are time dependent. The data are not consistent with a large number of individuals employing such a strategy: a high degree of impatience is observed and a substantial number of subjects are dynamically inconsistent.

Related to the issue of outside "investment" opportunities is the potential impact of high interest debt on experimental responses. Individuals with high-interest debt (e.g., payday or auto title loans not reported to credit bureaus) may pay down their expensive debt with earlier experimental payments, appearing relatively impatient. If such individuals also expect (rightly or wrongly) to not have such high-interest debt in the future, they may appear present-biased. Such a strategy of paying down high interest debt with experimental earnings would be employed by individuals who are unable to borrow on better terms than the high experimentally offered rates. Credit constrained individuals are one critical group for whom this may be true. It is therefore important to test the impact of credit constraints on experimental responses.

The credit report data enable us to determine precisely how much an individual is able to borrow on revolving accounts. Therefore, we have an exact measure of credit constraints. Additionally, we are able to develop other measures of liquidity positions and credit experience from tax and credit report data. Individual tax data allows us to measure the size of federal tax refunds (or liability), and whether or not tax refunds are direct deposited. This provides a picture of future liquidity (or constraint) and the timing of that future liquidity 13 Credit reports allow us to measure the number of loan accounts in an individual's credit history and whether or not an individual has sufficient credit history to be given a FICO score by the credit bureau.

Table 2 presents regressions using measured time preferences as the dependent variables. Columns 1 and 2 present OLS models in which the dependent variable is the average discount factor measure $(I D F)$. Columns 3 and 4 present interval regressions (Mark B. Stewart 1983) in which the dependent variable is the interval measure of an $I D F_{t, \tau}$. Columns 5 and 6 present OLS regressions in which Present $\operatorname{Bias}(=1)$ is the dependent variable. In each specification, we control for basic demographic characteristics of age, gender, and race. Columns 2, 4, and 6 additionally control for credit constraints (measured as the amount of available credit), for future

\footnotetext{
${ }^{13}$ Direct deposited refunds are supposed to be received in 7-10 business days, while mailed refunds take substantially longer.
} 
Table 2-Time Preferences

\begin{tabular}{|c|c|c|c|c|c|c|}
\hline \multirow[b]{2}{*}{ Dependent variable } & \multicolumn{2}{|c|}{$I D F$} & \multicolumn{2}{|c|}{ Interval of $I D F_{t, \tau}$} & \multicolumn{2}{|c|}{ Present bias $(=1)$} \\
\hline & (1) & (2) & (3) & (4) & $(5)$ & $(6)$ \\
\hline Age & $\begin{array}{l}-0.002 * * * \\
(0.001)\end{array}$ & $\begin{array}{l}-0.002^{* *} \\
(0.001)\end{array}$ & $\begin{array}{l}-0.002 * * * \\
(0.001)\end{array}$ & $\begin{array}{l}-0.002 * * \\
(0.001)\end{array}$ & $\begin{array}{l}-0.005^{* * *} \\
(0.002)\end{array}$ & $\begin{array}{c}-0.003 * * \\
(0.002)\end{array}$ \\
\hline Gender $($ male $=1)$ & $\begin{array}{l}-0.057 * * * \\
(0.018)\end{array}$ & $\begin{array}{l}-0.057 * * * \\
(0.019)\end{array}$ & $\begin{array}{l}-0.070 * * * \\
(0.022)\end{array}$ & $\begin{array}{l}-0.070 * * * \\
(0.023)\end{array}$ & $\begin{array}{l}0.092^{* * *} \\
(0.045)\end{array}$ & $\begin{array}{c}0.076 \\
(0.049)\end{array}$ \\
\hline Race (African American=1) & $\begin{array}{c}-0.010 \\
(0.020)\end{array}$ & $\begin{array}{c}-0.013 \\
(0.019)\end{array}$ & $\begin{array}{c}-0.011 \\
(0.024)\end{array}$ & $\begin{array}{c}-0.015 \\
(0.023)\end{array}$ & $\begin{array}{c}0.031 \\
(0.049)\end{array}$ & $\begin{array}{c}0.028 \\
(0.049)\end{array}$ \\
\hline $\ln ($ disposable income $)$ & & $\begin{array}{l}0.023^{* * *} \\
(0.009)\end{array}$ & & $\begin{array}{l}0.030^{* *} \\
(0.012)\end{array}$ & & $\begin{array}{r}-0.023 \\
(0.020)\end{array}$ \\
\hline Dependents & & $\begin{array}{r}-0.008 \\
(0.014)\end{array}$ & & $\begin{array}{r}-0.009 \\
(0.017)\end{array}$ & & $\begin{array}{c}0.009 \\
(0.035)\end{array}$ \\
\hline College experience $(=1)$ & & $\begin{array}{l}0.042^{* * *} \\
(0.018)\end{array}$ & & $\begin{array}{l}0.050 * * \\
(0.022)\end{array}$ & & $\begin{array}{l}0.181^{* * * *} \\
(0.048)\end{array}$ \\
\hline $\ln ($ credit amount available $)$ & & $\begin{array}{l}0.004^{*} \\
(0.003)\end{array}$ & & $\begin{array}{c}0.005^{*} \\
(0.003)\end{array}$ & & $\begin{array}{r}-0.000 \\
(0.007)\end{array}$ \\
\hline Tax refund(liability) amount & & $\begin{array}{c}0.000 \\
(0.000)\end{array}$ & & $\begin{array}{c}0.000 \\
(0.000)\end{array}$ & & $\begin{array}{c}-0.000^{*} \\
(0.000)\end{array}$ \\
\hline Direct deposit of refund $(=1)$ & & $\begin{array}{c}0.023 \\
(0.016)\end{array}$ & & $\begin{array}{c}0.028 \\
(0.020)\end{array}$ & & $\begin{array}{r}-0.026 \\
(0.043)\end{array}$ \\
\hline $\begin{array}{l}\text { Insufficient credit to be } \\
\text { scored }(=1)\end{array}$ & & $\begin{array}{l}0.040 * \\
(0.021)\end{array}$ & & $\begin{array}{c}0.048^{*} \\
(0.025)\end{array}$ & & $\begin{array}{c}0.080 \\
(0.054)\end{array}$ \\
\hline Loan accounts & & $\begin{array}{r}-0.001 \\
(0.001)\end{array}$ & & $\begin{array}{c}-0.002 \\
(0.002)\end{array}$ & & $\begin{array}{c}0.003 \\
(0.003)\end{array}$ \\
\hline Has present $(=1)$ & & & $\begin{array}{c}-0.079 * * * \\
(0.009)\end{array}$ & $\begin{array}{c}-0.079 * * * \\
(0.009)\end{array}$ & & \\
\hline Constant & $\begin{array}{l}0.975^{* * * *} \\
(0.029)\end{array}$ & $\begin{array}{l}0.697 * * * \\
(0.085)\end{array}$ & $\begin{array}{l}0.993^{* * * *} \\
(0.035)\end{array}$ & $\begin{array}{l}0.647 * * * \\
(0.108)\end{array}$ & $\begin{array}{l}0.441 * * * \\
(0.077)\end{array}$ & $\begin{array}{l}0.539 * * * \\
(0.202)\end{array}$ \\
\hline$R^{2} / \log$-likelihood & 0.07 & 0.12 & $-2,928.99$ & $-2,904.62$ & 0.03 & 0.07 \\
\hline Observations & 541 & 541 & 1,082 & 1,082 & 541 & 541 \\
\hline Individuals & 541 & 541 & 541 & 541 & 541 & 541 \\
\hline
\end{tabular}

Notes: Columns 1 and 2: OLS regressions. Dependent variable: IDF. Columns 3 and 4: Interval regressions (Stewart 1983). Dependent variable: Interval of $I D F_{t, \tau}$ measured from one of two price lists: $I D F_{0,1}$ and $I D F_{6,7}$. Columns 5 and 6: OLS regressions. Dependent variable: Present Bias $(=1)$. Robust standard errors clustered on individual level are in parentheses. Coefficients of dummies for year of study, missing gender, missing race, missing education are omitted from table.

*** Significant at the 1 percent level.

** Significant at the 5 percent level.

* Significant at the 10 percent level.

liquidity (measured as future tax refund quantity and whether or not it will be direct deposited), and for credit experience proxies (measured as whether credit history is sufficient to receive a FICO credit score and the number of credit history loan accounts). In columns 2,4 , and 6 , we also control for potentially endogenous demographics: income, number of dependents, and education. In the interval regression, whether or not the price list involves the present, Has Present $(=1)$, is also controlled for, and standard errors are clustered on the individual level.

Table 2 shows that our time preference measures are generally uncorrelated with credit constraints, future liquidity, or credit experience. This indicates that differential 
credit access, liquidity, and experience are unlikely to be drivers of experimental responses, and cannot explain the observed heterogeneity of present bias or its correlation with borrowing behavion 14

Table 2 also presents results relevant for the general discussion of time preferences and socio-demographic characteristics (see Harrison, Lau, and Williams 2002). Age is found to be negatively correlated with discount factors and whether or not individuals exhibit present bias. Men, though they have significantly lower discount factors than women, are equally likely to be present-biased. Individuals with higher income have higher measured discount factors, but are no more likely to be present-biased than others, while individuals of higher education have somewhat higher measured discount factors and are significantly more likely to be presentbiased. The observed correlation between education and present bias seems counterintuitive and requires attention in future research. Interestingly, the results of the interval regressions in columns 2 and 3 support the claim that individuals, on average, discount nonexponentially. Measured discount factors decrease when the present is involved, a pattern consistent with present-biased preferences (Frederick, Loewenstein, and O’Donoghue 2002).

\section{Results}

The relationship between individual present bias and credit card borrowing is explored by estimating models of the following form:

$$
\begin{aligned}
\text { Borrowing }_{i}= & \alpha+\gamma_{1} \text { IDF }_{i}+\gamma_{2} \text { PresentBias }_{i}+\gamma_{3} \text { FutureBias }_{i}+\gamma_{4} Y_{i} \\
& +\gamma_{5} \mathbf{X}_{i}+\varepsilon_{i} .
\end{aligned}
$$

Borrowing $_{i}$ is individual $i$ 's balance on revolving credit accounts on the study date. For the 2006 sample, we also examine balances on revolving accounts one year after the choice experiments. As Borrowing is censored at zero, we estimate tobit regressions. All results hold when estimating OLS regressions (see the Web Appendix).

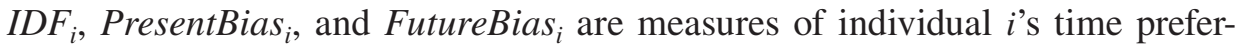
ences. $Y_{i}$ is a dummy for the year of study. The vector $\mathbf{X}_{i}$ reflects individual control variables, which include age, gender, race, education, income, and number of dependents claimed for tax purposes. In certain specifications, we control for credit card holdership, available credit limits, and FICO scores. Though presented in regression, we acknowledge that our evidence does not establish a causal link between present-biased preferences and borrowing behavior. Evidence in this paper should be interpreted as correlation between measured preferences and outstanding credit card balances.

\footnotetext{
${ }^{14} \mathrm{IDF}$ and PresentBias $(=1)$ are also found to be uncorrelated with credit constraints in regressions in which credit card holdership and available credit limits are the dependent variables (results available on request).
} 
Table 3-Present-Biased Preferences and Credit Card Borrowing

\begin{tabular}{|c|c|c|c|c|c|c|}
\hline & (1) & (2) & (3) & (4) & (5) & $(6)$ \\
\hline IDF & $\begin{array}{c}1,591.4 \\
(1,167.4) \\
{[0.13 ; 477.9]}\end{array}$ & $\begin{array}{c}1,653.3 \\
(1,181.2) \\
{[0.14 ; 494.7]}\end{array}$ & $\begin{array}{c}413.2 \\
(1,183.5) \\
{[0.04 ; 121.2]}\end{array}$ & $\begin{array}{c}2,998.2 \\
(3,978.8) \\
{[0.26 ; 1,019.1]}\end{array}$ & $\begin{array}{c}247.2 \\
(844.4) \\
{[0.02 ; 53.2]}\end{array}$ & $\begin{array}{c}520.3 \\
(1,095.3) \\
{[0.05 ; 141.6]}\end{array}$ \\
\hline Present bias $(=1)$ & $\begin{array}{c}1,304.4 * * \\
(508.3) \\
{[0.11 ; 402.2]}\end{array}$ & $\begin{array}{c}1,611.0 * * * \\
(516.4) \\
{[0.14 ; 498.7]}\end{array}$ & $\begin{array}{c}1,779.4 * * * \\
(518.8) \\
{[0.16 ; 542.9]}\end{array}$ & $\begin{array}{c}2,885.3 * * \\
(1255.8) \\
{[0.25 ; 1047.1]}\end{array}$ & $\begin{array}{c}1,874.0 * * * \\
(402.9) \\
{[0.20 ; 430.1]}\end{array}$ & $\begin{array}{c}2,013.6 * * * \\
(492.2) \\
{[0.20 ; 576.5]}\end{array}$ \\
\hline Future bias $(=1)$ & $\begin{array}{c}-270.5 \\
(811.7) \\
{[-0.02 ;-80.0]}\end{array}$ & $\begin{array}{c}-48.0 \\
(786.6) \\
{[-0.004 ;-14.3}\end{array}$ & $\begin{array}{c}-487.9 \\
(776.5) \\
{[-0.04 ;-139.0]}\end{array}$ & $\begin{array}{c}-389.4 \\
(1,341.0) \\
{[-0.03 ;-130.1]}\end{array}$ & $\begin{array}{c}-315.5 \\
(666.9) \\
{[-0.03 ;-66.1]}\end{array}$ & $\begin{array}{c}-689.8 \\
(732.1) \\
{[-0.06 ;-179.4]}\end{array}$ \\
\hline Constant and year of study & Yes & Yes & Yes & Yes & Yes & Yes \\
\hline $\begin{array}{l}\text { Exogenous control } \\
\text { variables }\end{array}$ & No & Yes & Yes & Yes & Yes & Yes \\
\hline Other socio-demographics & No & No & Yes & Yes & Yes & Yes \\
\hline Credit card information & No & No & No & No & Yes & No \\
\hline FICO score information & No & No & No & No & No & Yes \\
\hline \multicolumn{7}{|c|}{ For reference group (Present Bias $(=0)$ and Future Bias $(=0))$ : } \\
\hline Mean of DV & 786.8 & 786.8 & 786.8 & $1,027.7$ & 786.8 & 786.8 \\
\hline Mean of DV (if uncensored) & $2,028.1$ & $2,028.1$ & $2,028.1$ & $2,055.4$ & $2,028.1$ & $2,028.1$ \\
\hline LL & $-2,351.4$ & $-2,340.5$ & $-2,321.2$ & -663.34 & $-2,121.7$ & $-2,259.8$ \\
\hline Observations & 541 & 541 & 541 & 122 & 541 & 541 \\
\hline
\end{tabular}

Notes: Dependent variable: Outstanding balance on revolving accounts. In column 4, the dependent variable is the outstanding balance on revolving accounts one year after the experiment for the 2006 sample. Coefficient of tobit regressions. Robust standard errors are in parentheses. Marginal effects are in brackets [probability to be censored at 0; expected value of the dependent variable conditional on being uncensored]. Exogenous control variables: age, gender, race, and dummies for missing values. Other socio-demographics: $\ln$ (disposable income), number of dependents, college experience, and a dummy for missing information for education. Credit card information: dummy for having a revolving account and $\ln$ (credit limit). FICO score information: FICO score and a dummy for missing score.

*** Significant at the 1 percent level.

** Significant at the 5 percent level.

* Significant at the 10 percent level.

\section{A. Present Bias and Credit Card Borrowing}

Table 3 presents results from tobit regressions in which the dependent variable is total outstanding credit card balances. Column 1 presents results without control variables. To this basic specification, in column 2 , we add exogenous control variables: age, gender, and race. Column 3 adds further socio-demographics which may be correlated with time preferences: income, number of dependents, and college experience. Across specifications, present-biased individuals are found to have substantially higher credit card balances. Controlling for demographics, the estimated relationship between present bias and card borrowing is economically important, given participants' low incomes, and statistically significant at the 99 percent level. Similar to Harrison, Lau, and Williams (2002), the results show that IDFs are not significantly correlated with credit card debt levels 15

Marginal effects computed from the tobit model, in column 3, indicate that present-biased individuals are more likely to borrow, and borrow more than dynamically

\footnotetext{
${ }^{15}$ The effect of the $I D F$ is also modest in magnitude, as a change in a standard deviation of the IDF changes the probability of having any debt by only 2.5 percentage points.
} 
consistent individuals. Present bias is associated with a 16 percentage point increase in the probability of borrowing, and, conditional on borrowing, about $\$ 540$ more debt. Examining the average balance on revolving accounts for the reference group (see bottom of Table 3) indicates that this $\$ 540$ translates into approximately 27 percent higher credit card balances for present-biased individuals 16

In this study, time preferences and credit card debt are point-in-time measures. Recent shocks could potentially influence both card borrowing and measured preferences. A negative shock could increase credit card debt, and, if individuals were sufficiently liquidity constrained, could also impact measured preferences (see Meier and Sprenger (2009) for evidence that measured time preferences are stable over time and uncorrelated with changes in income or employment status). For this reason, we obtained the consent of the 2006 sample participants to analyze their credit report again in 2007.17 Column 4 presents this follow-up analysis. Tobit models are estimated with the dependent variable of credit card borrowing observed one year after the original time preference experiment. The results indicate that present bias remains substantially and significantly correlated with card borrowing even one year after time preferences are measured. Present-biased individuals are, again, found to be more likely to borrow, and borrow more than dynamically consistent individuals. This follow-up analysis suggests that recent short-lived shocks are not driving the correlation between present bias and credit card debt.

Credit access and credit limits play an interesting role in the discussion of present bias and borrowing 18 Not only may individuals choose their credit limits and number of credit cards, but firms may grant high or low credit limits, or deny credit entirely. Column 5 controls for the results of these interactions by adding, as explanatory variables, whether or not individuals have a credit card and their remaining available credit limit across all accounts (in natural logarithm). Controlling for these credit constraints, present bias is, again, associated with more credit card borrowing. Present-biased individuals are roughly 20 percentage points more likely to borrow, and, conditional on borrowing, have around $\$ 430$ more debt than dynamically consistent individuals 19

In general, the demand for credit card borrowing is responsive to interest rate changes (Gross and Souleles 2002). Controlling for the price of credit in our analysis is a key concern. Credit reports do not provide direct interest rate information. However, individual credit scores can be used as an interest rate proxy given the prevalence of risk-based pricing in credit markets (Furletti 2003). Column 6 in Table 3 accounts for possible differences in interest rates across subjects by controlling for

\footnotetext{
${ }^{16}$ The results hold when analyzing only individuals with positive amounts of debt, and when using the natural logarithm of the outstanding balance (see the Web Appendix).

${ }^{17}$ For one individual, in the 2006 sample, the outstanding balance increased from almost $\$ 4,000$ in 2006 to over $\$ 35,000$ in 2007 . This individual's 2007 revolving debt level was twice as high as the next highest debt level. The follow-up analysis in column 4 excludes this outlier.

${ }^{18}$ Borrowers aware of their present bias may want to restrict their borrowing opportunities, and may choose a lower credit limit or not to have a credit card at all. For a discussion of "sophisticated" borrowing, see Heidhues and Kőszegi (2008).

${ }^{19}$ Results from analysis of a payment behavior question similar to the Survey of Consumer Finances indicate that present-biased individuals are also less likely to self-report that they normally pay their credit card in full at the end of the month. Results may be obtained from the authors on request.
} 
FICO scores 20 Controlling for FICO scores as a proxy for interest rates, present bias is associated with both a higher probability of borrowing and conditionally more debt.

In sum, the results indicate that individuals who exhibit present bias are between 15 and 20 percentage points more likely to borrow on their credit cards. Conditional upon borrowing, present-biased individuals have around \$400-\$580 (about 25 percent) more debt than dynamically consistent individuals. The relationship between present bias and credit card debt is maintained when controlling for demographics, credit constraints (both credit access and limits), and a proxy for interest rates. One year after the original time preference experiment, present bias remains significantly correlated with card borrowing.

\section{B. Robustness Tests}

This section tests the robustness of the obtained results: first, to changes in calculating time preferences; and second, to controlling for risk attitudes and relaxing the sample restriction criteria.

Columns 1-3 in Table 4 present results with alternative specifications of present bias. In column 1 , we calculate the ratio $I D F_{6,7} / I D F_{0,1}$. This ratio takes on the value one for dynamically consistent individuals, is above one for present-biased individuals, and is below one for future-biased individuals. This measure captures the direction and the intensity of dynamic inconsistency. We find that more present-biased individuals have higher debt levels. In column 2 , we fit experimental choices with a quasi-hyperbolic discounting, $\beta, \delta$, model. 21 The results indicate that present-biased individuals, i.e., those with lower $\beta$, have significantly higher revolving balances. In column 3, we add the information from a third timeframe in which $t=0$ and $\tau=6$. This third time frame gives an additional indication of individual dynamic inconsistency. The composite measure $\overline{\text { PresentBias }}$ takes on the value of one if $I D F_{0,1}<I D F_{6,7}$ and $I D F_{0,1}<I D F_{0,6} \sqrt{22}$ The results are robust to adding the choices from this third timeframe to the analysis.

Columns 4-6 in Table 4 show the robustness of the results to including individual risk attitudes and to changes in sample restrictions. Individual risk attitudes are taken from a survey question on general risk attitudes previously validated in a large, representative sample (Dohmen et al. 2005) ${ }^{23}$ Column 4 indicates that the results are maintained with the inclusion of this measure, providing suggestive evidence that individual risk preferences do not impact the association between card borrowing and present bias. Column 5 includes individuals who exhibit multiple switching points and make it difficult to calculate a discount factor. For these individuals, we take their first switching point to calculate their IDFs. The results are unchanged.

\footnotetext{
${ }^{20}$ Individuals with insufficient credit history to be scored are bottom-coded as 0 . We also include an indicator variable for whether or not an individual is scored.

${ }^{21}$ The calculations are $\delta=I D F_{6,7} ; \beta=I D F_{0,1} / I D F_{6,7}$.

${ }^{22}$ The composite measure $\overline{\text { FutureBias }}$ is similarly generated and is given the value one when $I D F_{0,1}>I D F_{6,7}$ and $I D F_{0,1}>I D F_{0,6}$.

${ }^{23}$ Participants answer the following question: "How willing are you to take risks in general? (on a scale from "unwilling" to "fully prepared") on a scale from 0 to 7 in 2006 and from 0 to 10 in 2007 . We rescale the answer to be on an 11-point scale in both years.
} 
TABle 4-Robustness Tests

\begin{tabular}{|c|c|c|c|c|c|c|}
\hline & $(1)$ & (2) & (3) & (4) & (5) & (6) \\
\hline$I D F_{6,7} / I D F_{0,1}$ & $\begin{array}{c}1,264.1^{* *} \\
(607.6)\end{array}$ & & & & & \\
\hline$\beta$ & & $\begin{array}{c}-2,516.6^{* *} \\
(1,019.4)\end{array}$ & & & & \\
\hline$\delta$ & & $\begin{array}{c}888.5 \\
(1,190.4)\end{array}$ & & & & \\
\hline$\overline{I D F}$ & & & $\begin{array}{c}113.8 \\
(1,533.5)\end{array}$ & & & \\
\hline$\overline{\text { PresentBias }}(=1)$ & & & $\begin{array}{l}1,588.6^{* * * *} \\
(581.3)\end{array}$ & & & \\
\hline$\overline{\text { FutureBias }}(=1)$ & & & $\begin{array}{r}273.9 \\
(1,156.3)\end{array}$ & & & \\
\hline IDF & & & & $\begin{array}{c}-533.6 \\
(1,281.1)\end{array}$ & $\begin{array}{c}1,804.6 \\
(1,360.7)\end{array}$ & $\begin{array}{c}528.5 \\
(1,426.3)\end{array}$ \\
\hline Present bias $(=1)$ & & & & $\begin{array}{l}1,895.0 * * * \\
(558.3)\end{array}$ & $\begin{array}{l}1,681.9 * * * \\
(561.9)\end{array}$ & $\begin{array}{c}1,418.1^{* *} \\
(596.4)\end{array}$ \\
\hline Future bias $(=1)$ & & & & $\begin{array}{r}-308.4 \\
(818.8)\end{array}$ & $\begin{array}{l}-54.0 \\
(801.1)\end{array}$ & $\begin{array}{r}-1,086.1 \\
(844.7)\end{array}$ \\
\hline Constant and year of study & Yes & Yes & Yes & Yes & Yes & Yes \\
\hline Exogenous control variables & Yes & Yes & Yes & Yes & Yes & Yes \\
\hline Other socio-demographics & Yes & Yes & Yes & Yes & Yes & Yes \\
\hline Risk attitudes & No & No & No & Yes & No & No \\
\hline Including multiple switchers & No & No & No & No & Yes & No \\
\hline $\begin{array}{l}\text { Non-missing control } \\
\text { variables }\end{array}$ & No & No & No & No & No & Yes \\
\hline LL & $-2,327.78$ & $-2,325.60$ & $-2,324.70$ & $-2,033.28$ & $-2,659.19$ & $-1,797.90$ \\
\hline Observations & 541 & 541 & 541 & 463 & 606 & 420 \\
\hline
\end{tabular}

Notes: Dependent variable: Outstanding balance on revolving accounts. Coefficient of tobit regressions. Robust standard errors are in parentheses. Exogenous control variables: age, gender, race, and dummies for missing values. Other socio-demographics: $\ln$ (disposable income), number of dependents, college experience, and a dummy for missing information for education. Risk attitudes: based on question "How willing are you to take risks in general? (on a scale from 0 "unwilling" to 7 (in 2006) or 10 (in 2007) "fully prepared"). The answers are rescaled to be on an 11-point scale for both years.

*** Significant at the 1 percent level.

** Significant at the 5 percent level.

* Significant at the 10 percent level.

Column 6 excludes all individuals for whom any demographic control variables are missing, and the results do not change substantially.

\section{Conclusions}

This paper directly investigates the relationship between individual present bias and credit card borrowing. Unlike previous studies analyzing either aggregate or self-reported borrowing, we present evidence from a unique field study combining incentivized choice experiments and objective administrative data on credit card borrowing. 
We find that present-biased individuals are more likely to borrow and, conditionally, borrow more than dynamically consistent individuals. The relationship between present bias and credit card debt is maintained when controlling for demographics, credit constraints (both access and limits), and a proxy for interest rates. One year after the original time preference experiment, present bias remains significantly correlated with card borrowing. The results are unaffected by changes in the calculation of present bias or sample selection criteria.

The finding that directly measured present bias correlates with credit card borrowing gives critical support to behavioral economics models of present-biased preferences in consumer choice. This paper opens up a number of avenues for future research. First, the results presented here are correlative. Future research should focus on the more difficult problem of exploring the theoretically proposed causal link between present bias and borrowing. Second, our efforts focus exclusively on credit card borrowing and not other forms of debt (e.g., installment loans, mortgages, etc.). Credit card debt is identified as being psychologically different from other forms of debt (e.g., Drazen Prelec and Duncan Simester 2001), and, so, future work should determine whether or not our results extend to other borrowing behavior. Third, our analysis shows nothing with regard to the discussion of sophistication and naïvete in present bias. A number of policy implications with regard to card borrowing depend critically on borrower sophistication (see, for example, Colin Camerer et al. 2003). Research should investigate which present-biased consumers are and are not cognizant of their own present bias.

\section{REFERENCES}

-Adams, William, Liran Einav, and Jonathan Levin. 2009. "Liquidity Constraints and Imperfect Information in Subprime Lending." American Economic Review, 99(1): 49-84.

-Andersen, Steffen, Glenn W. Harrison, Morten I. Lau, and Elisabet E. Rutström. 2008. "Eliciting Risk and Time Preferences." Econometrica, 76(3): 583-618.

-Ariely, Dan, and Klaus Wertenbroch. 2002. "Procrastination, Deadlines, and Performance: SelfControl by Precommitment." Psychological Science, 13(3): 219-24.

-Ashraf, Nava, Dean Karlan, and Wesley Yin. 2006. "Tying Odysseus to the Mast: Evidence from a Commitment Savings Product in the Philippines." Quarterly Journal of Economics, 121(2): 635-72.

Avery, Robert B., Paul S. Calem, Glenn B. Canner, and Raphael W. Bostic. 2003. "An Overview of Consumer Data and Credit Reporting." Federal Reserve Bulletin, 89(2): 47-73.

-Bernheim, B. Douglas, and Antonio Rangel. 2004. "Addiction and Cue-Triggered Decision Processes." American Economic Review, 94(5): 1558-90.

- Bertaut, Carol, Michael Haliassos, and Michael Keiter. 2009. "Credit Card Debt Puzzles and Debt Revolvers for Self Control.” Review of Finance. 13(4): 657-92.

- Bertrand, Marianne, Sendhil Mullainathan, and Eldar Shafir. 2004. "A Behavioral-Economics View of Poverty." American Economic Review, 94(2): 419-23.

Camerer, Colin, Samuel Issacharoff, George Loewenstein, Ted O'Donoghue, and Matthew Rabin. 2003. "Regulation for Conservatives: Behavioral Economics and the Case for 'Asymmetric Paternalism." University of Pennsylvania Law Review, 151(1): 1211-54.

Chabris, Christopher F., David Laibson, Carrie L. Morris, Jonathon P. Schuldt, and Dmitry Taubinsky. 2008. "Measuring Intertemporal Preferences Using Response Times." National Bureau of Economic Research Working Paper 14353.

Coller, Maribeth, and Melonie B. Williams. 1999. "Eliciting Individual Discount Rates." Experimental Economics, 2(2): 107-27.

-Cubitt, Robin P., and Daniel Read. 2007. "Can Intertemporal Choice Experiments Elicit Time Preferences for Consumption?” Experimental Economics, 10(4): 369-89. 
Dohmen, Thomas, Armin Falk, David Huffman, and Uwe Sunde. 2006. "Dynamic Inconsistency Predicts Self-Control Problems in Humans." Unpublished.

Dohmen, Thomas, Armin Falk, David Huffman, Uwe Sunde, Jürgen Schupp, and Gert G. Wagner. Forthcoming. "Individual Risk Attitudes: New Evidence from a Large, Representative, Experimentally-Validated Survey." Journal of the Economic Association.

Eckel, Catherine, Cathleen Johnson, and Claude Montmarquette. 2005. "Saving Decisions of the Working Poor: Short- and Long-Term Horizons." In Field Experiments in Economics, Vol. 10, ed. Jeffrey P. Carpenter, Glenn W. Harrison, and John A. List, 219-60. Greenwich, CT: JAI Press.

Fehr, Ernst. 2002. "The Economics of Impatience." Nature, 415(6869): 269-72.

-Frederick, Shane, George Loewenstein, and Ted O'Donoghue. 2002. "Time Discounting and Time Preference: A Critical Review." Journal of Economic Literature, 40(2): 351-401.

-Fudenberg, Drew, and David K. Levine. 2006. "A Dual-Self Model of Impulse Control." American Economic Review, 96(5): 1449-76.

Furletti, Mark. 2003. "Credit Card Pricing Developments and Their Disclosure." Federal Reserve Bank of Philadelphia Payment Cards Center Discussion Paper 03-02.

Gine, Xavier, Dean Karlan, and Jonathan Zinman. 2008. "Put Your Money Where Your Butt Is: A Commitment Contract for Smoking Cessation." Unpublished.

-Gross, David B., and Nicholas S. Souleles. 2002. "Do Liquidity Constraints and Interest Rates Matter for Consumer Behavior? Evidence from Credit Card Data." Quarterly Journal of Economics, 117(1): 149-85.

-Gul, Faruk, and Wolfgang Pesendorfer. 2001. "Temptation and Self-Control." Econometrica, 69(6): $1403-35$.

Harrison, Glenn W., Morten I. Lau, and Melonie B. Williams. 2002. "Estimating Individual Discount Rates in Denmark: A Field Experiment." American Economic Review, 92(5): 1606-17.

Harrison, Glenn W., Morten Igel Lau, Elisabet E. Rutström, and Melonie B. Sullivan. 2005. "Eliciting Risk and Time Preferences Using Field Experiments: Some Methodological Issues." In Field Experiments in Economics, Vol. 10, ed. Jeffrey P. Carpenter, Glenn W. Harrison, and John A. List, 125-218. Greenwich, CT: JAI Press.

Heidhues, Paul, and Botond Kôszegi. Forthcoming. "Exploiting Naivete about Self-Control in the Credit Market." American Economic Review.

Johnson, Kathleen W. 2004. "Convenience or Necessity? Understanding the Recent Rise in Credit Card Debt." Board of Governors of the Federal Reserve System Finance and Economics Discussion Series 2004-47.

-Karlan, Dean, and Jonathan Zinman. 2008. "Lying About Borrowing." Journal of the European Economic Association, 6(2-3): 510-21.

-Laibson, David. 1997. "Golden Eggs and Hyperbolic Discounting." Quarterly Journal of Economics, 112(2): 443-77.

Laibson, David, Andrea Repetto, and Jeremy Tobacman. 2008. "Estimating Discount Functions with Consumption Choices over the Lifecycle." Unpublished.

Loewenstein, George, and Ted O'Donoghue. 2004. "Animal Spirits: Affective and Deliberative Processes in Economic Behavior." Unpublished.

- McClure, Samuel M., David I. Laibson, George Loewenstein, and Jonathan D. Cohen. 2004. "Separate Neural Systems Value Immediate and Delayed Monetary Rewards.” Science, 306(5695): 503-07.

-McClure, Samuel M., Keith M. Ericson, David I. Laibson, George Loewenstein, and Jonathan D. Cohen. 2007. "Time Discounting for Primary Rewards." Journal of Neuroscience, 27(21): 5796-5804.

Meier, Stephan, and Charles Sprenger. 2008. "Discounting Financial Literacy: Time Preferences and Participation in Financial Education Programs." Unpublished.

Meier, Stephan, and Charles Sprenger. 2009. "Stability of Time Preferences.” Unpublished.

O'Donoghue, Ted, and Matthew Rabin. 1999. "Doing It Now or Later." American Economic Review, 89(1): 103-24.

Oster, Sharon M., and Fiona M. Scott Morton. 2005. "Behavioral Biases Meet the Market: The Case of Magazine Subscription Prices." B. E. Journal of Economic Analysis and Policy: Advances in Economic Analysis and Policy, 5(1): 1-30.

-Phelps, Edmund S., and Robert A. Pollak. 1968. "On Second-Best National Saving and Game-Equilibrium Growth.” Review of Economic Studies, 35(3): 185-199.

-Prelec, Drazen, and Duncan Simester. 2001. "Always Leave Home Without it: A Further Investigation of the Credit-Card Effect on Willingness to Pay." Marketing Letters, 12(1): 5-12.

-Rabin, Matthew. 2000. "Risk Aversion and Expected-Utility Theory: A Calibration Theorem." Econometrica, 68(5): 1281-92. 
Reuben, Ernesto, Paola Sapienza, and Luigi Zingales. Forthcoming. "Time Discounting for Primary and Monetary Rewards." Economics Letters.

Shui, Haiyan, and Lawrence M. Ausubel. 2005. "Time Inconsistency in the Credit Card Market." Unpublished.

Skiba, Paige Marta, and Jeremy Tobacman. 2007. "Payday Loans, Uncertainty, and Discounting: Explaining Patterns of Borrowing, Repayment, and Default." Unpublished.

-Stewart, Mark B. 1983. "On Least Squares Estimation When the Dependent Variable Is Grouped." Review of Economic Studies, 50(4): 737-53.

Strotz, Robert H. 1956. "Myopia and Inconsistency in Dynamic Utility Maximization." Review of Economic Studies, 23(3): 165-80.

Tanaka, Tomomi, Colin Camerer, and Quang Nguyen. Forthcoming. "Risk and Time Preferences: Experimental and Household Data from Vietnam." American Economic Review.

Zinman, Jonathan. 2009. "Where Is the Missing Credit Card Debt? Clues and Implications." Review of Income and Wealth, 55(2): 249-65. 


\section{This article has been cited by:}

1. Andrea L. Patalano, Sydney L. Lolli, Charles A. Sanislow. 2020. Brief report on the relationship between temporal discount rate and error related negativity for immediate versus future choice options. International Journal of Psychophysiology 151, 1-6. [Crossref]

2. Yoonseok Choi. 2020. Macroeconomic implications of dynamically inconsistent preferences. Economic Modelling 87, 267-279. [Crossref]

3. Zachary Breig. 2020. Prediction and Model Selection in Experiments. Economic Record . [Crossref]

4. Marco Frigerio, Cristina Ottaviani, Daniela Vandone. 2020. A meta-analytic investigation of consumer over-indebtedness: The role of impulsivity. International Journal of Consumer Studies 25. . [Crossref]

5. Joanna Stavins. 2020. Credit Card Debt and Consumer Payment Choice: What Can We Learn from Credit Bureau Data?. Journal of Financial Services Researcb 38. . [Crossref]

6. Tim Friehe, Markus Pannenberg. 2020. Time preferences and political regimes: evidence from reunified Germany. Journal of Population Economics 33:1, 349-387. [Crossref]

7. James Andreoni, Alison Sanchez. 2020. FOOLING MYSELF OR FOOLING OBSERVERS? AVOIDING SOCIAL PRESSURES BY MANIPULATING PERCEPTIONS OF DESERVINGNESS OF OTHERS. Economic Inquiry 58:1, 12-33. [Crossref]

8. C. Badarinza, V. Balasubramaniam, T. Ramadorai. 2019. The Household Finance Landscape in Emerging Economies. Annual Review of Financial Economics 11:1, 109-129. [Crossref]

9. Ariel Kalil, Susan E. Mayer, Sebastian Gallegos. 2019. Using behavioral insights to increase attendance at subsidized preschool programs: The Show Up to Grow Up intervention. Organizational Bebavior and Human Decision Processes . [Crossref]

10. Guido Friebel, Michael Kosfeld, Gerd Thielmann. 2019. Trust the Police? Self-Selection of Motivated Agents into the German Police Force. American Economic Journal: Microeconomics 11:4, 59-78. [Abstract] [View PDF article] [PDF with links]

11. Daniel J. Benjamin, David Laibson, Walter Mischel, Philip K. Peake, Yuichi Shoda, Alexandra Steiny Wellsjo, Nicole L. Wilson. 2019. Predicting mid-life capital formation with pre-school delay of gratification and life-course measures of self-regulation. Journal of Economic Bebavior \& Organization . [Crossref]

12. Gladys Byegon, Josephat Cheboi, Ronald Bonuke. 2019. Mediating Effects of Financial Innovations between Behavioral Factors and Financial Inclusion of Micro Enterprises in Kenya. SEISENSE Journal of Management 2:6, 49-64. [Crossref]

13. Daniel Ringo. 2019. Parental Credit Constraints and Child College Attendance. Education Finance and Policy 14:4, 548-571. [Crossref]

14. Siti Nurazira Mohd Daud, Ainulashikin Marzuki, Nursilah Ahmad, Zurina Kefeli. 2019. Financial Vulnerability and Its Determinants: Survey Evidence from Malaysian Households. Emerging Markets Finance and Trade 55:9, 1991-2003. [Crossref]

15. Ralph A Ssebagala. 2019. Poor health as a precursor to consumer debt distress in South Africa. Development Southern Africa 36:4, 519-536. [Crossref]

16. M. Lukas, M. Nöth. 2019. Interest rate changes and borrower search behavior. Journal of Economic Behavior \& Organization 163, 172-189. [Crossref] 
17. Garth Heutel. 2019. Prospect theory and energy efficiency. Journal of Environmental Economics and Management 96, 236-254. [Crossref]

18. T Le Cotty, E Maître d'Hôtel, R Soubeyran, J Subervie. 2019. Inventory Credit as a Commitment Device to Save Grain Until the Hunger Season. American Journal of Agricultural Economics 101:4, 1115-1139. [Crossref]

19. Gopi Shah Goda, Matthew Levy, Colleen Flaherty Manchester, Aaron Sojourner, Joshua Tasoff. 2019. PREDICTING RETIREMENT SAVINGS USING SURVEY MEASURES OF EXPONENTIAL-GROWTH BIAS AND PRESENT BIAS. Economic Inquiry 57:3, 1636-1658. [Crossref]

20. Jing Jian Xiao, Nilton Porto. 2019. Present bias and financial behavior. FINANCIAL PLANNING REVIEW 2:2. . [Crossref]

21. Naveed Chehrazi, Peter W. Glynn, Thomas A. Weber. 2019. Dynamic Credit-Collections Optimization. Management Science 65:6, 2737-2769. [Crossref]

22. T. R. Harmon-Kizer. 2019. Let the Borrower Beware: Towards a Framework for Debiasing Rollover Behavior in the Payday Loan Industry. Journal of Consumer Policy 42:2, 245-266. [Crossref]

23. Qiyan Ong, Walter Theseira, Irene Y. H. Ng. 2019. Reducing debt improves psychological functioning and changes decision-making in the poor. Proceedings of the National Academy of Sciences 116:15, 7244-7249. [Crossref]

24. Thor Gamst-Klaussen, Piers Steel, Frode Svartdal. 2019. Procrastination and Personal Finances: Exploring the Roles of Planning and Financial Self-Efficacy. Frontiers in Psychology 10. . [Crossref]

25. Kyu Kim, Gal Zauberman. 2019. The effect of music tempo on consumer impatience in intertemporal decisions. European Journal of Marketing 53:3, 504-523. [Crossref]

26. Marco Castillo, Jeffrey L Jordan, Ragan Petrie. 2019. Discount Rates of Children and High School Graduation. The Economic Journal 129:619, 1153-1181. [Crossref]

27. Kirsten I. M. Rohde. 2019. Measuring Decreasing and Increasing Impatience. Management Science 65:4, 1700-1716. [Crossref]

28. Alastair Irvine, Marjon van der Pol, Euan Phimister. 2019. A comparison of professional and private time preferences of General Practitioners. Social Science \& Medicine 222, 256-264. [Crossref]

29. Amelie Gamble, Tommy Gärling, Patrik Michaelsen. Young Adults' Consumption Desires, Feelings of Financial Scarcity and Borrowing 89-108. [Crossref]

30. Moritz Lukas, Markus Noeth. 2019. Commitment and Borrower Heterogeneity: Evidence from Revolving Consumer Credit. SSRN Electronic Journal . [Crossref]

31. Moritz Lukas, Markus Noeth. 2019. Maturity Choice and Reference Points. SSRN Electronic Journal . [Crossref]

32. Alexis Direr. 2019. Bringing Present Bias Back to the Present. SSRN Electronic Journal . [Crossref]

33. Adam Eric Greenberg, Hal E. Hershfield. 2018. Financial decision making. Consumer Psychology Review 17. . [Crossref]

34. John Gathergood, Daniel Wylie. 2018. Why are some households so poorly insured?. Journal of Economic Behavior \& Organization 156, 1-12. [Crossref] 
35. Vasileios Kotsidis. 2018. Call to Action: Intrinsic Motives and Material Interests. Games 9:4, 92. [Crossref]

36. Sule Alan, Seda Ertac. 2018. Fostering Patience in the Classroom: Results from Randomized Educational Intervention. Journal of Political Economy 126:5, 1865-1911. [Crossref]

37. Suzanne B. Shu, Stephen D. Shu. 2018. The Psychology of Decumulation Decisions During Retirement. Policy Insights from the Bebavioral and Brain Sciences 5:2, 216-223. [Crossref]

38. Sun Young Ahn, Ya-Hui Kuo, Joyce Serido, Soyeon Shim. 2018. Direct and Interaction Effects of Cognitive Bias and Anxiety on Credit Misuse among U.S. College Students. Family and Environment Research 56:5, 447-460. [Crossref]

39. Melanie Lührmann, Marta Serra-Garcia, Joachim Winter. 2018. The Impact of Financial Education on Adolescents' Intertemporal Choices. American Economic Journal: Economic Policy 10:3, 309-332. [Abstract] [View PDF article] [PDF with links]

40. Felipe Kast, Stephan Meier, Dina Pomeranz. 2018. Saving more in groups: Field experimental evidence from Chile. Journal of Development Economics 133, 275-294. [Crossref]

41. Franz Fuerst, Ramandeep Singh. 2018. How present bias forestalls energy efficiency upgrades: A study of household appliance purchases in India. Journal of Cleaner Production 186, 558-569. [Crossref]

42. Kim Abildgren, Niels Lynggård Hansen, Andreas Kuchler. 2018. Overoptimism and house price bubbles. Journal of Macroeconomics 56, 1-14. [Crossref]

43. Junying Liu, Zhipeng Cui, Xiaojun Yang, Martin Skitmore. 2018. Experimental Investigation of the Impact of Risk Preference on Construction Bid Markups. Journal of Management in Engineering 34:3, 04018003. [Crossref]

44. Diego Aycinena, Lucas Rentschler. 2018. Discounting and Digit Ratio: Low 2D:4D Predicts Patience for a Sample of Females. Frontiers in Behavioral Neuroscience 11. . [Crossref]

45. Shyamal Chowdhury, Matthias Sutter, Klaus Zimmermann. 2018. Evaluating Intergenerational Persistence of Economic Preferences: A Large Scale Experiment with Families in Bangladesh. SSRN Electronic Journal . [Crossref]

46. Joshua Tasoff, Wenjie Zhang. 2018. The Performance of Time-Preference and Risk-Preference Elicitations in Survey. SSRN Electronic Journal . [Crossref]

47. Daniel Gottlieb, Xingtan Zhang. 2018. Long-Term Contracting with Time-Inconsistent Agents. SSRN Electronic Journal . [Crossref]

48. Cristian Badarinza, Vimal Balasubramaniam, Tarun Ramadorai. 2018. The Household Finance Landscape in Emerging Economies. SSRN Electronic Journal . [Crossref]

49. Lena Detlefsen, Andreas Friedl, Katharina Lima de Miranda, Ulrich Schmidt, Matthias Sutter. 2018. Are Economic Preferences Shaped by the Family Context? The Impact of Birth Order and Siblings' Sex Composition on Economic Preferences. SSRN Electronic Journal . [Crossref]

50. Ana Odorović. 2018. The 'new' paternalism in consumer credit regulation: When, why, and how?. Anali Pravnog fakulteta u Beogradu 66:4, 156-176. [Crossref]

51. John McCollough, Mehmet Fatih Bayramoglu, Miao He. 2018. Transitioning into a 'throwaway planet'. International Journal of Consumer Studies 42:1, 131-140. [Crossref]

52. Pavlo Illiashenko. 2017. Behavioral Finance: Household Investment and Borrowing Decisions. Visnyk of the National Bank of Ukraine :242, 15-29. [Crossref] 
53. George Okello Candiya Bongomin, John C. Munene, Joseph Mpeera Ntayi, Charles Akol Malinga. 2017. Financial literacy in emerging economies. Managerial Finance 43:12, 1310-1331. [Crossref]

54. Ananda Ganguly, Joshua Tasoff. 2017. Fantasy and Dread: The Demand for Information and the Consumption Utility of the Future. Management Science 63:12, 4037-4060. [Crossref]

55. Max M. Owens, Joshua C. Gray, Michael T. Amlung, Assaf Oshri, Lawrence H. Sweet, James MacKillop. 2017. Neuroanatomical foundations of delayed reward discounting decision making. NeuroImage 161, 261-270. [Crossref]

56. Sumit Agarwal, Souphala Chomsisengphet, Cheryl Lim. 2017. What Shapes Consumer Choice and Financial Products? A Review. Annual Review of Financial Economics 9:1, 127-146. [Crossref]

57. Petr Houdek, Nina Rybáková. 2017. The Impulsiveness of the Roma Minority, the Czech Majority and the Psychological, Demographic, and Socioeconomic Correlations. Acta Oeconomica Pragensia 25:4, 13-38. [Crossref]

58. Britta Gauly. 2017. The Intergenerational Transmission of Attitudes: Analyzing Time Preferences and Reciprocity. Journal of Family and Economic Issues 38:2, 293-312. [Crossref]

59. Shrinidhi Subramaniam, Anthony DeFulio, Brantley P. Jarvis, August F. Holtyn, Kenneth Silverman. 2017. Earning, Spending, and Drug Use in a Therapeutic Workplace. The Psychological Record 67:2, 273-283. [Crossref]

60. Michael A. Kuhn, Peter Kuhn, Marie Claire Villeval. 2017. Decision-environment effects on intertemporal financial choices: How relevant are resource-depletion models?. Journal of Economic Behavior \& Organization 137, 72-89. [Crossref]

61. Angela Boatman, Brent J. Evans. 2017. How Financial Literacy, Federal Aid Knowledge, and Credit Market Experience Predict Loan Aversion for Education. The ANNALS of the American Academy of Political and Social Science 671:1, 49-68. [Crossref]

62. Yun Peng, Ruzhi Xu, Huawei Zhao, Zhizheng Zhou, Ni Wu, Ying Yang. Random Walk Based Trade Reference Computation for Personal Credit Scoring 122-127. [Crossref]

63. Michal Grinstein-Weiss, Blair D. Russell, William G. Gale, Clinton Key, Dan Ariely. 2017. Behavioral Interventions to Increase Tax-Time Saving: Evidence from a National Randomized Trial. Journal of Consumer Affairs 51:1, 3-26. [Crossref]

64. Kodi B. Arfer, Christian C. Luhmann. 2017. Time-Preference Tests Fail to Predict Behavior Related to Self-control. Frontiers in Psychology 8. . [Crossref]

65. Paul Heidhues, Botond Köszegi, Takeshi Murooka. 2017. Inferior Products and Profitable Deception. The Review of Economic Studies 84:1, 323-356. [Crossref]

66. Hong Ru, Antoinette Schoar. 2017. Do Credit Card Companies Screen for Behavioral Biases?. SSRN Electronic Journal . [Crossref]

67. John Gathergood, Daniel Wylie. 2017. Why Are Some Households So Poorly Insured?. SSRN Electronic Journal . [Crossref]

68. Victor Stango, Joanne Yoong, Jonathan Zinman. 2017. The Quest for Parsimony in Behavioral Economics: New Methods and Evidence on Three Fronts. SSRN Electronic Journal . [Crossref]

69. Claudia Cerrone, Leonhard K. Lades. 2017. Sophisticated and Naave Procrastination: An Experimental Study. SSRN Electronic Journal . [Crossref]

70. Stephen J. Brown. 2017. Do Individuals Use Credit Cards Rationally?. SSRN Electronic Journal . [Crossref] 
71. Victor Stango, Joanne Yoong, Jonathan Zinman. 2017. Quicksand or Bedrock for Behavioral Economics? Assessing Foundational Empirical Questions. SSRN Electronic Journal . [Crossref]

72. Daniel Horn, Hubert Janos Kiss. 2017. Which Preferences Associate with School Performance? Lessons from a University Classroom Experiment. SSRN Electronic Journal . [Crossref]

73. Kartik Athreya, Jose Mustre-del-Rio, Juan M. SSnchez. 2017. The Persistence of Financial Distress. SSRN Electronic Journal . [Crossref]

74. Natalia Montinari, Emma Runnemark, Erik Wengstrrm. 2017. Self-Scanning and Self-Control: A Field Experiment on Real-Time Feedback and Shopping Behavior. SSRN Electronic Journal . [Crossref]

75. Pia R. mname Pinger. 2017. Thinking About Tomorrow? Predicting Experimental Choice Behavior and Life Outcomes from a Survey Measure of Present Bias. SSRN Electronic Journal . [Crossref]

76. John Gathergood, Hiroaki Sakaguchi, Neil Stewart, Joerg Weber. 2017. Learning, Liquidity and Credit Card Fees. SSRN Electronic Journal . [Crossref]

77. Kanshukan Rajaratnam, Peter A. Beling, George A. Overstreet. 2016. Models of sequential decision making in consumer lending. Decision Analytics 3:1. . [Crossref]

78. Daniel J. Benjamin, James J. Choi, Geoffrey Fisher. 2016. Religious Identity and Economic Behavior. Review of Economics and Statistics 98:4, 617-637. [Crossref]

79. Gal Zauberman, Oleg Urminsky. 2016. Consumer intertemporal preferences. Current Opinion in Psychology 10, 136-141. [Crossref]

80. John A. List, Michael K. Price. 2016. The Use of Field Experiments in Environmental and Resource Economics. Review of Environmental Economics and Policy 10:2, 206-225. [Crossref]

81. Fiona Maccallum, George A. Bonanno. 2016. The Economics of Losing a Loved One. Clinical Psychological Science 4:4, 683-690. [Crossref]

82. David Åkerlund, Bart H. H. Golsteyn, Hans Grönqvist, Lena Lindahl. 2016. Time discounting and criminal behavior. Proceedings of the National Academy of Sciences 113:22, 6160-6165. [Crossref]

83. Leandro S. Carvalho, Silvia Prina, Justin Sydnor. 2016. The effect of saving on risk attitudes and intertemporal choices. Journal of Development Economics 120, 41-52. [Crossref]

84. Matteo M. Galizzi, Marisa Miraldo, Charitini Stavropoulou. 2016. In Sickness but Not in Wealth. Medical Decision Making 36:4, 503-517. [Crossref]

85. Giuseppe Albanese, Guido De Blasio, Paolo Sestito. 2016. My parents taught Me. Evidence on the family transmission of values. Journal of Population Economics 29:2, 571-592. [Crossref]

86. Christine L. Exley. 2016. Excusing Selfishness in Charitable Giving: The Role of Risk. The Review of Economic Studies 83:2, 587-628. [Crossref]

87. Bruno Karoubi, Régis Chenavaz, Corina Paraschiv. 2016. Consumers' perceived risk and hold and use of payment instruments. Applied Economics 48:14, 1317-1329. [Crossref]

88. Leandro S. Carvalho, Stephan Meier, Stephanie W. Wang. 2016. Poverty and Economic DecisionMaking: Evidence from Changes in Financial Resources at Payday. American Economic Review 106:2, 260-284. [Abstract] [View PDF article] [PDF with links]

89. Radha Bhattacharya, Andrew Gill, Denise Stanley. 2016. The Effectiveness of Financial Literacy Instruction: The Role of Individual Development Accounts Participation and the Intensity of Instruction. Journal of Financial Counseling and Planning 27:1, 20-35. [Crossref] 
90. Anastassia Fedyk. 2016. Asymmetric Naivete: Beliefs About Self-Control. SSRN Electronic Journal . [Crossref]

91. Giovanni Mastrobuoni, David A Rivers. 2016. Criminal Discount Factors and Deterrence. SSRN Electronic Journal . [Crossref]

92. Franz Fuerst. 2016. Harvesting the Low-Hanging Fruit: A Behavioural Study of Energy-Efficient Household Appliance Purchases in India. SSRN Electronic Journal . [Crossref]

93. Elif Incekara Halafir. 2016. Awareness of Low Self-Control: Theory and Evidence. SSRN Electronic Journal . [Crossref]

94. Marit Hinnosaar. 2016. Time Inconsistency and Alcohol Sales Restrictions. SSRN Electronic Journal . [Crossref]

95. Thomas Buser. 2016. Measuring Responsiveness to Feedback as a Personal Trait. SSRN Electronic Journal . [Crossref]

96. Carlotta Mariotto. 2016. Competition for Lending in the Internet Era: The Case of Peer-toPeer Lending Marketplaces in the USA. SSRN Electronic Journal . [Crossref]

97. Marieke Bos, Chloe Le Coq, Peter van Santen. 2016. Economic Scarcity and Consumerss Credit Choice. SSRN Electronic Journal . [Crossref]

98. Damon Clark, David Gill, Victoria L. Prowse, Mark Rush. 2016. Using Goals to Motivate College Students: Theory and Evidence from Field Experiments. SSRN Electronic Journal . [Crossref]

99. Sumit Agarwal, Souphala Chomsisengphet, Cheryl Lim. 2016. What Shapes Consumer Choice and Financial Products? - A Review. SSRN Electronic Journal . [Crossref]

100. James J. Choi. 2015. Contributions to Defined Contribution Pension Plans. Annual Review of Financial Economics 7:1, 161-178. [Crossref]

101. Charles Sprenger. 2015. An Endowment Effect for Risk: Experimental Tests of Stochastic Reference Points. Journal of Political Economy 123:6, 1456-1499. [Crossref]

102. Ned Augenblick, Muriel Niederle, Charles Sprenger. 2015. Working over Time: Dynamic Inconsistency in Real Effort Tasks. The Quarterly Journal of Economics 130:3, 1067-1115. [Crossref]

103. Jonathan Zinman. 2015. Household Debt: Facts, Puzzles, Theories, and Policies. Annual Review of Economics 7:1, 251-276. [Crossref]

104. Charles Sprenger. 2015. Judging Experimental Evidence on Dynamic Inconsistency. American Economic Review 105:5, 280-285. [Abstract] [View PDF article] [PDF with links]

105. Stephan Meier, Charles D. Sprenger. 2015. Temporal Stability of Time Preferences. Review of Economics and Statistics 97:2, 273-286. [Crossref]

106. Elif Incekara-Hafalir. 2015. Credit Card Competition and Naive Hyperbolic Consumers. Journal of Financial Services Research 47:2, 153-175. [Crossref]

107. Thomas Randolph Beard, James A. Leitzel. 2015. Compensated Live Kidney Donations. SSRN Electronic Journal . [Crossref]

108. Theresa Kuchler. 2015. Sticking to Your Plan: Hyperbolic Discounting and Credit Card Debt Paydown. SSRN Electronic Journal . [Crossref]

109. Andrew G. Meyer. 2015. Explaining the Fixed Cost Component of Discounting: The Importance of Students' Liquidity Constraints. SSRN Electronic Journal . [Crossref]

110. Alain Cohn, Michel Andrr Marrchal. 2015. Laboratory Measure of Cheating Predicts Misbehavior at School. SSRN Electronic Journal . [Crossref] 
111. Julia M. Puaschunder. 2015. Time Time Time. SSRN Electronic Journal . [Crossref]

112. Sophie Clot, Charlotte Y. Stanton. 2014. Present bias predicts participation in payments for environmental services: Evidence from a behavioral experiment in Uganda. Ecological Economics 108, 162-170. [Crossref]

113. Jan-Emmanuel De Neve, James H. Fowler. 2014. Credit card borrowing and the monoamine oxidase A (MAOA) gene. Journal of Economic Behavior \& Organization 107, 428-439. [Crossref]

114. Matthew Harding, Alice Hsiaw. 2014. Goal setting and energy conservation. Journal of Economic Bebavior \& Organization 107, 209-227. [Crossref]

115. Timothy Gubler, Lamar Pierce. 2014. Healthy, Wealthy, and Wise. Psychological Science 25:9, 1822-1830. [Crossref]

116. Hristina Dzhogleva, Cait Poynor Lamberton. 2014. Should Birds of a Feather Flock Together? Understanding Self-Control Decisions in Dyads. Journal of Consumer Research 41:2, 361-380. [Crossref]

117. Jonathan Zinman. 2014. Consumer Credit: Too Much or Too Little (or Just Right)?. The Journal of Legal Studies 43:S2, S209-S237. [Crossref]

118. Matteo M. Galizzi. 2014. What Is Really Behavioral in Behavioral Health Policy? And Does It Work?. Applied Economic Perspectives and Policy 36:1, 25-60. [Crossref]

119. Bijou Yang, David Lester. 2014. A subcultural study of credit card debt and foreclosures. Applied Economics 46:3, 323-328. [Crossref]

120. Jeffrey Carpenter, Tyler Williams. 2014. Peer Monitoring and Microcredit: Field Experimental Evidence from Paraguay. Oxford Development Studies 42:1, 111-135. [Crossref]

121. Caterina Giannetti. 2014. Time Preference Instability, Financial and Working Status. SSRN Electronic Journal . [Crossref]

122. Sumit Agarwal, Yongheng Deng, Jia He. 2014. Time Preferences, Mortgage Choice and Mortgage Default. SSRN Electronic Journal . [Crossref]

123. Felipe Kast, Dina Pomeranz. 2014. Saving More to Borrow Less: Experimental Evidence from Access to Formal Savings Accounts in Chile. SSRN Electronic Journal . [Crossref]

124. Giuseppe Albanese, Guido de Blasio, Paolo Sestito. 2014. My Parents Taught Me. Evidence on the Family Transmission of Values. SSRN Electronic Journal . [Crossref]

125. Jeremy Burke, Jill Luoto, Francisco PPrez-Arce. 2014. Soft versus Hard Commitments: A Test on Savings Behaviors. SSRN Electronic Journal . [Crossref]

126. Jonathan Zinman. 2014. Household Debt: Facts, Puzzles, Theories, and Policies. SSRN Electronic Journal . [Crossref]

127. Alexandra M. Brown, J. Michael Collins, Maximilian D. Schmeiser, Carly Urban. 2014. State Mandated Financial Education and the Credit Behavior of Young Adults. SSRN Electronic Journal . [Crossref]

128. Timothy (Jun) Lu, Olivia S. Mitchell, Stephen P. Utkus, Jean A. Young. 2014. Borrowing from the Future: 401(k) Plan Loans and Loan Defaults. SSRN Electronic Journal . [Crossref]

129. Sule Alan, Seda Ertac. 2014. Good Things Come to Those Who (are Taught How to) Wait: Results from a Randomized Educational Intervention on Time Preference. SSRN Electronic Journal . [Crossref]

130. S. Duke Han, Patricia A. Boyle, Lei Yu, Debra A. Fleischman, Konstantinos Arfanakis, David A. Bennett. 2013. Ventromedial PFC, parahippocampal, and cerebellar connectivity are associated with temporal discounting in old age. Experimental Gerontology 48:12, 1489-1498. [Crossref] 
131. Brishti Guha, Prabal Roy Chowdhury. 2013. Micro-finance competition: Motivated microlenders, double-dipping and default. Journal of Development Economics 105, 86-102. [Crossref]

132. Shweta Arya, Catherine Eckel, Colin Wichman. 2013. Anatomy of the credit score. Journal of Economic Behavior \& Organization 95, 175-185. [Crossref]

133. Catherine Eckel, Cathleen Johnson, Claude Montmarquette. 2013. Human capital investment by the poor: Informing policy with laboratory experiments. Journal of Economic Behavior \& Organization 95, 224-239. [Crossref]

134. Stephan Meier, Charles D. Sprenger. 2013. Discounting financial literacy: Time preferences and participation in financial education programs. Journal of Economic Bebavior \& Organization 95, 159-174. [Crossref]

135. Sera Linardi, Tomomi Tanaka. 2013. Competition as a savings incentive: A field experiment at a homeless shelter. Journal of Economic Behavior \& Organization 95, 240-251. [Crossref]

136. STEPHANIE MOULTON, CÄZILIA LOIBL, ANYA SAMAK, J. MICHAEL COLLINS. 2013. Borrowing Capacity and Financial Decisions of Low-to-Moderate Income First-Time Homebuyers. Journal of Consumer Affairs 47:3, 375-403. [Crossref]

137. Michal Bauer, Julie Chytilová. 2013. Women, Children and Patience: Experimental Evidence from Indian Villages. Review of Development Economics 17:4, 662-675. [Crossref]

138. Justine S. Hastings, Brigitte C. Madrian, William L. Skimmyhorn. 2013. Financial Literacy, Financial Education, and Economic Outcomes. Annual Review of Economics 5:1, 347-373. [Crossref]

139. Richard Disney, John Gathergood. 2013. Financial literacy and consumer credit portfolios. Journal of Banking \& Finance 37:7, 2246-2254. [Crossref]

140. Lucie Kalousova, Sarah A. Burgard. 2013. Debt and Foregone Medical Care. Journal of Health and Social Behavior 54:2, 204-220. [Crossref]

141. Olivier Toubia, Eric Johnson, Theodoros Evgeniou, Philippe Delquié. 2013. Dynamic Experiments for Estimating Preferences: An Adaptive Method of Eliciting Time and Risk Parameters. Management Science 59:3, 613-640. [Crossref]

142. Matthias Sutter,, Martin G. Kocher,, Daniela Glätzle-Rützler,, Stefan T. Trautmann. 2013. Impatience and Uncertainty: Experimental Decisions Predict Adolescents' Field Behavior. American Economic Review 103:1, 510-531. [Abstract] [View PDF article] [PDF with links]

143. Jennifer S. Lerner, Ye Li, Elke U. Weber. 2013. The Financial Costs of Sadness. Psychological Science 24:1, 72-79. [Crossref]

144. Sigitas Karpavicius. 2013. The Cost of Capital and Optimal Financing Policy in the Dynamic Setting. SSRN Electronic Journal . [Crossref]

145. Michael Kuhn, Peter J. Kuhn, Marie-Claire Villeval. 2013. The Importance of the Cognitive Environment for Intertemporal Choice. SSRN Electronic Journal . [Crossref]

146. Giuseppe Albanese, Guido de Blasio, Paolo Sestito. 2013. Trust and Preferences: Evidence from Survey Data. SSRN Electronic Journal . [Crossref]

147. Peter Debbaut, Andra C. Ghent, Marianna Kudlyak. 2013. Are Young Borrowers Bad Borrowers? Evidence from the Credit CARD Act of 2009. SSRN Electronic Journal . [Crossref]

148. Peter H. Huang. 2013. Mental Time Travel Induced Illusions About Financial, Ethical, and Tortious Behavior. SSRN Electronic Journal . [Crossref]

149. Sergio Beraldo, Raul Caruso, Gilberto Turati. 2013. Life is Now! Time Preferences and Crime: Aggregate Evidence from the Italian Regions. SSRN Electronic Journal . [Crossref] 
150. David Adam Friedman. 2013. Public Health Regulation and the Limits of Paternalism. SSRN Electronic Journal . [Crossref]

151. Eva Woelbert, Arno Riedl. 2013. Measuring Time and Risk Preferences: Reliability, Stability, Domain Specificity. SSRN Electronic Journal . [Crossref]

152. Jonathan Zinman. 2013. Consumer Credit: Too Much or Too Little (or Just Right)?. SSRN Electronic Journal . [Crossref]

153. Ananda R. Ganguly, Joshua Tasoff. 2013. Fantasy and Dread: An Experimental Test of Attentional Anticipatory Utility. SSRN Electronic Journal . [Crossref]

154. James Andreoni,, Charles Sprenger. 2012. Estimating Time Preferences from Convex Budgets. American Economic Review 102:7, 3333-3356. [Abstract] [View PDF article] [PDF with links]

155. Patricia A Boyle, Lei Yu, Eisuke Segawa, Robert S Wilson, Aron S Buchman, David I Laibson, David A Bennett. 2012. Association of cognition with temporal discounting in community based older persons. BMC Geriatrics 12:1. . [Crossref]

156. Stephen Burks, Jeffrey Carpenter, Lorenz Götte, Aldo Rustichini. 2012. Which measures of time preference best predict outcomes: Evidence from a large-scale field experiment. Journal of Economic Behavior \& Organization 84:1, 308-320. [Crossref]

157. Luisa Anderloni, Emanuele Bacchiocchi, Daniela Vandone. 2012. Household financial vulnerability: An empirical analysis. Research in Economics 66:3, 284-296. [Crossref]

158. Angela C. M. de Oliveira, Catherine Eckel, Rachel T. A. Croson. 2012. The Stability of Social Preferences in a Low-Income Neighborhood. Southern Economic Journal 79:1, 15-45. [Crossref]

159. Fabian Kosse, Friedhelm Pfeiffer. 2012. Impatience among preschool children and their mothers. Economics Letters 115:3, 493-495. [Crossref]

160. Michal Bauer,, Julie Chytilová,, Jonathan Morduch. 2012. Behavioral Foundations of Microcredit: Experimental and Survey Evidence from Rural India. American Economic Review 102:2, 1118-1139. [Abstract] [View PDF article] [PDF with links]

161. Paul Dolan, Antony Elliott, Robert Metcalfe, Ivo Vlaev. 2012. Influencing Financial Behavior: From Changing Minds to Changing Contexts. Journal of Behavioral Finance 13:2, 126-142. [Crossref]

162. TOMOMI TANAKA, TAKESHI MUROOKA. 2012. SELF-CONTROL PROBLEMS AND CONSUMPTION-SAVING DECISIONS: THEORY AND EMPIRICAL EVIDENCE*. Japanese Economic Review 63:1, 23-37. [Crossref]

163. E. Duquette, N. Higgins, J. Horowitz. 2012. Farmer Discount Rates: Experimental Evidence. American Journal of Agricultural Economics 94:2, 451-456. [Crossref]

164. Jason MacGregor, Brett Wilkinson. The Effect of Economic Patriotism on Tax Morale and Attitudes Toward Tax Compliance 159-180. [Crossref]

165. Stephan Meier, Charles D. Sprenger. 2012. Time Discounting Predicts Creditworthiness. Psychological Science 23:1, 56-58. [Crossref]

166. Kurt W. Rotthoff. 2012. Discrete Utility Jumps: The Value of Money in the Hand. SSRN Electronic Journal . [Crossref]

167. Dean S. Karlan, Jonathan Zinman. 2012. Borrow Less Tomorrow: Behavioral Approaches to Debt Reduction. SSRN Electronic Journal . [Crossref]

168. Ari Hyytinen, Hanna Putkuri. 2012. Household Optimism and Borrowing. SSRN Electronic Journal . [Crossref] 
169. J. Michael Collins, Maximilian D. Schmeiser, Carly Urban. 2012. Protecting Homeowners: Foreclosure Counseling Policies and Modifications of Mortgage Terms. SSRN Electronic Journal . [Crossref]

170. Sumit Agarwal, Amit Bubna, Molly Lipscomb. 2012. Timing to the Statement: Understanding Fluctuations in Consumer Credit Use. SSRN Electronic Journal . [Crossref]

171. Kristen R. Hamilton, Marc N. Potenza. 2012. Relations among Delay Discounting, Addictions, and Money Mismanagement: Implications and Future Directions. The American Journal of Drug and Alcohol Abuse 38:1, 30-42. [Crossref]

172. Benjamin Levinger, Marques Benton, Stephan Meier. 2011. The Cost of Not Knowing the Score: Self-Estimated Credit Scores and Financial Outcomes. Journal of Family and Economic Issues 32:4, 566-585. [Crossref]

173. T. van Huizen, J. Plantenga. 2011. Labour Market Effects of Unemployment Accounts: Insights from Behavioural Economics. CESifo Economic Studies 57:4, 581-604. [Crossref]

174. Cristina Ottaviani, Daniela Vandone. 2011. Impulsivity and household indebtedness: Evidence from real life. Journal of Economic Psychology 32:5, 754-761. [Crossref]

175. Nicholas Burger, Gary Charness, John Lynham. 2011. Field and online experiments on selfcontrol. Journal of Economic Behavior \& Organization 77:3, 393-404. [Crossref]

176. John Gathergood. 2011. Self-Control, Financial Literacy and Consumer Over-Indebtedness. SSRN Electronic Journal . [Crossref]

177. Shinsuke Ikeda, Myong-Il Kang. 2011. Generalized Hyperbolic Discounting, Borrowing Aversion, and Debt Holding. SSRN Electronic Journal . [Crossref]

178. Meta Brown, Andrew F. Haughwout, Donghoon Lee, Wilbert van der Klaauw. 2011. Do We Know What We Owe? A Comparison of Borrower- and Lender-Reported Consumer Debt. SSRN Electronic Journal . [Crossref]

179. Daniela Vandone, Emanuele Bacchiocchi, Luisa Anderloni. 2011. Household Financial Vulnerability: An Empirical Analysis. SSRN Electronic Journal . [Crossref]

180. David J. Hardisty, Katherine Thompson, David Krantz, Elke U. Weber. 2011. How to Measure Discount Rates? An Experimental Comparison of Three Methods. SSRN Electronic Journal . [Crossref]

181. Colin F. Camerer. 2011. The Promise and Success of Lab-Field Generalizability in Experimental Economics: A Critical Reply to Levitt and List. SSRN Electronic Journal . [Crossref]

182. Fabian Kosse, Friedhelm Pfeiffer. 2011. Impatience Among Preschool Children and Their Mothers. SSRN Electronic Journal . [Crossref]

183. Paul Heidhues, Botond Kőszegi. 2010. Exploiting Naïvete about Self-Control in the Credit Market. American Economic Review 100:5, 2279-2303. [Abstract] [View PDF article] [PDF with links]

184. Gharad Bryan, Dean Karlan, Scott Nelson. 2010. Commitment Devices. Annual Review of Economics 2:1, 671-698. [Crossref]

185. Daniel J. Benjamin,, James J. Choi,, A. Joshua Strickland. 2010. Social Identity and Preferences. American Economic Review 100:4, 1913-1928. [Abstract] [View PDF article] [PDF with links]

186. Jan-Emmanuel De Neve, James H. Fowler. 2010. The MAOA Gene Predicts Credit Card Debt. SSRN Electronic Journal . [Crossref]

187. Mei Wang, Marc Oliver Rieger, Thorsten Hens. 2010. How Time Preferences Differ: Evidence from 45 Countries. SSRN Electronic Journal . [Crossref] 
188. Kristopher S. Gerardi, Lorenz F. Goette, Stephan Meier. 2010. Financial Literacy and Subprime Mortgage Delinquency: Evidence from a Survey Matched to Administrative Data. SSRN Electronic Journal . [Crossref]

189. Jeffrey P. Carpenter, Tyler Williams. 2010. Moral Hazard, Peer Monitoring, and Microcredit: Field Experimental Evidence from Paraguay. SSRN Electronic Journal . [Crossref]

190. Ernesto Reuben, Paola Sapienza, Luigi Zingales. 2010. Procrastination and Impatience. SSRN Electronic Journal . [Crossref]

191. Shruti Surachita. Inter-Temporal Choice and Its Relevance in Consumer's Credit Behavior 17-38. [Crossref] 